\title{
Molecular Mechanisms and Management of a Cutaneous Inflammatory Disorder: Psoriasis
}

\author{
Yu Ri Woo ${ }^{1}$ (D), Dae Ho Cho ${ }^{2}$ and Hyun Jeong Park ${ }^{1, *}$ \\ 1 Department of Dermatology, Yeouido St. Mary's Hospital, College of Medicine, The Catholic \\ University of Korea, Seoul 07345, Korea; w1206@naver.com \\ 2 Department of Life Science, Sookmyung Women's University, Seoul 04310, Korea; cdhkor@sookmyung.ac.kr \\ * Correspondence: hjpark@catholic.ac.kr; Tel.: +82-2-3779-1230; Fax: +82-2-783-7604
}

Received: 30 November 2017; Accepted: 7 December 2017; Published: 11 December 2017

\begin{abstract}
Psoriasis is a complex chronic inflammatory cutaneous disorder. To date, robust molecular mechanisms of psoriasis have been reported. Among diverse aberrant immunopathogenetic mechanisms, the current model emphasizes the role of Th1 and the IL-23/Th17 axis, skin-resident immune cells and major signal transduction pathways involved in psoriasis. The multiple genetic risk loci for psoriasis have been rapidly revealed with the advent of a novel technology. Moreover, identifying epigenetic modifications could bridge the gap between genetic and environmental risk factors in psoriasis. This review will provide a better understanding of the pathogenesis of psoriasis by unraveling the complicated interplay among immunological abnormalities, genetic risk foci, epigenetic modification and environmental factors of psoriasis. With advances in molecular biology, diverse new targets are under investigation to manage psoriasis. The recent advances in treatment modalities for psoriasis based on targeted molecules are also discussed.
\end{abstract}

Keywords: biologics; epigenetics; genetics; interleukin-23; psoriasis; signaling pathway; small molecules; T helper 17 cells

\section{Introduction}

Psoriasis is a chronic relapsing cutaneous inflammatory disorder. The skin lesion of psoriasis is classically characterized by erythematous papules and plaques with white thick scales. Clinical phenotypes of psoriasis include psoriasis vulgaris, guttate psoriasis, inverse psoriasis, erythrodermic psoriasis and pustular psoriasis [1]. Different clinical phenotypes of the disease can be observed even in the same patients in the course of the disease progression.

The prevalence rate of psoriasis varies in different populations, ranging from $0.91-8.5 \%$ [2]. Enamandram et al. [3] surmised that the reason for such diverse prevalence rates of psoriasis among different populations might be associated with genetic susceptibility and environmental factors.

Many hypotheses have been suggested to identify possible pathogenic models for psoriasis. Since the clinical characteristic of psoriasis is manifested as thick scales with the histopathological characteristic of epidermal hyperplasia, psoriasis has been regarded as a disorder of keratinocytes. However, increased discoveries in the pathophysiology of psoriasis have revealed that perturbed differentiation and proliferation of keratinocytes might be due to the interplay between immune cells and keratinocytes in a genetically-susceptible patient. In this review, recent progress in molecular mechanisms of psoriasis that contribute to the initiation and development of psoriasis will be described, especially in the field of immunologic abnormalities, signaling pathways, genetics and epigenetics. New promising treatment targets for psoriasis based on these associated molecular pathways of psoriasis will also be discussed. 


\section{Immunological Abnormalities}

\subsection{The Roles of Adaptive T Cell Immunity and the IL-23/Th17 Axis in Psoriasis}

Th cells have long been recognized as a key pathogenic factor in psoriasis. The majority of infiltrating $\mathrm{CD}^{+} \mathrm{T}$ cells in psoriasis are Th1 cells characterized by their production of Th1 cytokines such as interferon- $\gamma$ (IFN- $\gamma$ ), interleukin (IL)-2 and IL-12. Elevated serum levels of Th1 cytokines have been observed in the sera of patients with psoriasis. They are also correlated with the severity of psoriasis [4]. Among various Th1 cytokines, the role of IFN- $\gamma$ in psoriasis has been postulated as an activator of monocytes, dendritic cells (DCs) and endothelial cells [5]. In addition, IFN- $\gamma$ affects keratinocytes by inhibiting apoptosis [5], suggesting its role in inducing the hyperproliferation of keratinocytes that is observed in psoriasis. However, anti-IFN- $\gamma$ therapy for managing psoriasis has produced unfavorable results, implying that other pathways are more closely related to the pathogenic mechanisms of psoriasis [6]. With the advances of research in the immunopathogenesis of psoriasis, a recent pathogenic model for psoriasis has postulated the importance of the IL-23/Th17 immune axis (Figure 1). Among the diverse molecules related to this axis, tumor necrosis factor (TNF)- $\alpha$, IL-23, IL-17 and IL-22 have been established as the key regulators of psoriasis based on the profound effects of biologics targeting these molecules.

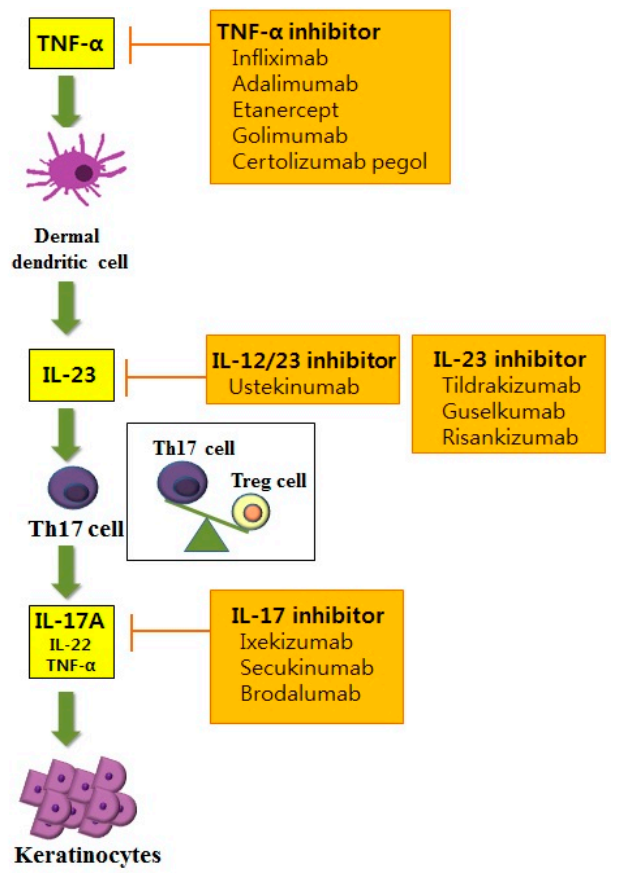

Figure 1. The prevailing model of the IL-23/Th17 axis in the immunopathogenesis of psoriasis and newly-developed targeting molecules in psoriasis. TNF, tumor necrosis factor; Th, T helper cell; Treg, regulatory T cell; IL, interleukin.

The increased expression of IL-23 and its receptor has been observed in the lesional skin in patients with psoriasis compared to that of the normal controls [7]. IL-23 is secreted by DCs and macrophages and stimulates the differentiation and proliferation of the Th17 cell. Thereby, IL-23 serves as an upstream regulatory cytokine in psoriasis. IL-23 has a potent role for activating Th17 cells to release IL-17, IL-22 and TNF- $\alpha$, which are associated with further inflammatory responses [8]. Moreover, IL-23 induces the production of TNF- $\alpha$ from macrophages. This cytokine is also capable of stimulating hyperproliferation of keratinocytes. Indeed, direct dermal injection of IL-23 can induce epidermal hyperplasia commonly observed in skin samples of psoriasis patients [9]. 
Stimulated by IL-23, Th17 cells primarily secret IL-17. Besides Th17 cells, a recent study demonstrated the production of IL-17 in neutrophils and mast cells [10]. The IL-17 cytokine family consists of six subtypes (IL-17A-F) [11]. Among them, IL-17A is a key molecule for amplifying inflammation in psoriasis through the propagation of the production of various proinflammatory cytokines and chemokines [11]. Especially, IL-17A can activate keratinocytes to express various proinflammatory cytokines including IL-6, IL-8 and TNF- $\alpha$ and chemokines including CCL20, CXCL1, CXCL2, CXCL3, CXCL5 and CXCL8. IL-17A induces the increased expression of antimicrobial peptides including $\beta$-defensin and S100A families, thereby activating the innate immune system [12]. IL-17A can also potentiate the hyperproliferation of keratinocytes and inhibit the differentiation of keratinocytes [10]. Rizzo et al. [13] have injected recombinant murine IL-23 into the skin of IL-17A knockout mice and found little epidermal hyperplasia. In patients with psoriasis, the elevated expression of IL-17 mRNA has been found in skin from patients with psoriasis compared with healthy controls [14]. Moreover, the serum levels of IL-17A are positively correlated with the severity of psoriasis [4].

Besides IL-17A, Th17 cells also secret IL-22. Recently, the new subset of effector T cells that secrete IL-22 was discovered and named Th22 cells. Like Th17 cells, the differentiation and maintenance of Th22 cells are also affected by IL-23 [15]. In patients with psoriasis, the serum levels of IL-22 are significantly elevated in patients with psoriasis compared to normal controls [16]. IL-22 can increase the expression of antimicrobial peptides that are elevated in psoriasis patients in cooperation with IL-17 [12]. IL-22 can also augment the expression of cytokines and chemokines and synergistically regulate downstream effector responses associated with the Th17 pathway [17]. In addition, IL-22 can influence epidermal hyperproliferation and differentiation of keratinocytes [18]. Indeed, in an in vivo model, IL-22 mediates the IL-23-associated keratinocyte hyperproliferation via STAT3 signaling, implicating the involvement of an interplay between two cytokines [19]. A recent study has found that mice deficient in IL-22 binding protein (IL-22BP) show aggravation of psoriasis with increased expression of IL-22-associated antimicrobial peptides [20]. Injection of IL-22BP neutralizing antibody, a natural IL-22 inhibitor, also reproduces the exacerbation of skin inflammation found in the mouse model of psoriasis [20]. Moreover, the ratio of IL-22/IL-22BP is positively correlated with psoriasis severity [20], implying the influence of IL-22 in pathogenetic immune circuits of psoriasis.

It is important to know that the efficacy of Th17 cytokines on the formation of the psoriatic lesion is influenced by these cytokines and by inflammatory mediators such as TNF- $\alpha$. TNF- $\alpha$ can be produced by DCs, activated T cells, macrophages, Langerhans cells and keratinocytes [21]. Increased TNF- $\alpha$ levels are found in various chronic inflammatory disorders including psoriasis, psoriatic arthritis and rheumatoid arthritis [22,23]. In addition to its proinflammatory effects, the pivotal effects of TNF- $\alpha$ on the pathogenesis of psoriasis are exerted through the regulated production of IL-23 from DCs. Thus, TNF- $\alpha$ modulates the key pathway of the IL-23/Th17 axis in psoriasis. In addition, reduced expression of co-stimulatory factors including CD86 and CD11c was observed in lesional DCs after treatment with TNF- $\alpha$ inhibitor [24]. Moreover, treatment with TNF- $\alpha$ inhibitor can result in the reduced expression of IL-17 and IL-22 on the lesional psoriatic skin in patients with psoriasis. These observations indicate that the disturbed interaction between DCs and T cells after exposure to TNF- $\alpha$ inhibitor might result in the reduced expression of IL-23 and decrease the expression of Th17 effector cytokines, including IL-17 and IL-22. Besides upstream regulation of IL-23, TNF- $\alpha$ can act synergistically with IL-17A on epidermal keratinocytes, resulting in overexpression of various psoriasis-related proinflammatory gene including S100A7, IL-8, DEFB4, CCL20 and CXCL1 [25].

Since perturbed IL-23/Th17 pathways can promote chronic skin inflammation and epidermal hyperplasia in psoriasis, targeting this pathway is attracting much interest [17]. In addition to Th17 cells and their associated molecules, the role of regulatory $\mathrm{T}$ (Treg) cells and their association with Th17 cells has been identified in psoriasis. Treg cells are characterized by their expression of CD4, CD25 and forkhead/winged helix transcription factor 3 (FoxP3) [26]. Treg cells play an important role in suppressing inflammation of other immune cells such as $\mathrm{T}$ cells, thereby affecting homeostasis of the 
immune system. Various chronic inflammatory diseases show dysregulation in Treg cells, including rheumatoid arthritis, atopic dermatitis, pemphigus vulgaris and psoriasis [27-30]. Infiltration of both Th17 cells and Treg cells is increased in patients with psoriasis [26]. In addition, the ratio of infiltrating Th17 cells to Treg cells on psoriatic skin is positively correlated with the severity of psoriasis. The activity of Treg cells in peripheral blood is decreased in patients with psoriasis, and the number of Treg cells in psoriatic skin lesions is normal [30]. However, the same study found that the capability of Treg cells suppressing $\mathrm{CD} 4^{+} \mathrm{T}$ cells is impaired in patients with psoriasis [30]. Therefore, the impaired immunoregulatory function of Treg cells in psoriasis might propagate excessive $\mathrm{T}$ cell proliferation, further aggravating inflammatory reactions.

\subsection{Role of Skin Resident Cells in Psoriasis}

\subsubsection{Keratinocytes in Psoriasis}

Although the pathogenesis of psoriasis has long been explained on the basis of perturbance in $\mathrm{T}$ cell populations, keratinocytes also play an important role in the activation of certain $\mathrm{T}$ cell populations by expressing various autoantigens. Keratinocytes could assist activation of $\mathrm{T}$ cells upon exposure to bacterial, viral or fungal pathogens in psoriasis. Especially, streptococcal superantigen is a major autoantigen in psoriasis. The production of streptococcal superantigen requires $\mathrm{T}$ cell presentation to MHC class II molecules expressed on keratinocytes [31]. In addition, the overexpression of antimicrobial peptides LL-37 produced from keratinocytes has also been observed in psoriatic skin [32]. LL-37 acts as an autoantigen and stimulates the activation of $\mathrm{T}$ cells in psoriatic patients.

In addition, an imbalance between differentiation and proliferation of keratinocytes occurs in patients with psoriasis [33]. Lesional psoriatic epidermal keratinocytes upregulate K6/K16, which is a marker for hyperproliferation [33,34]. The downregulation of $\mathrm{K} 1 / \mathrm{K} 10$, a marker for terminal differentiation, in the suprabasal layer has also been observed in the suprabasal layer in the lesional epidermal skin in patients with psoriasis $[33,34]$. The accelerated proliferation of basal keratinocytes and differentiation of spinous and granular keratinocytes are the key features observed in psoriasis and wound repair [35]. Therefore, this process is called regenerative maturation [36]. During the process of regenerative maturation, altered expression levels of genes including CDSM and genes encoding EDC have been found in keratinocytes of psoriatic plaques [35]. In addition, expression of proteins, such as S100A9 and S100A9, associated with regeneration of epidermal keratinocytes also functions as chemotactic factors for neutrophils in psoriasis [35]. The cytokines released from neutrophils, such as TNF- $\alpha$ and IFN- $\gamma$, could promote the production of adhesion molecules and chemokines in keratinocytes and could intensify the recruitment of neutrophils in epidermal keratinocytes [35]. Therefore, the pathways involved in regenerative maturation in psoriasis are associated with activation of complex dysregulated immunological circuits.

Keratinocytes from patients with psoriasis have aberrant responses for the production of proinflammatory cytokines, including IL-1, IL-8 and IL-15 [37]. Especially, the dysregulation in IL-1 receptor signaling has been observed in the lesional skin of patients with psoriasis [38]. The epidermal barrier disruption frequently occurs in psoriasis, resulting in the increased expression of IL-1 and IL-1 receptor antagonists [33]. Along with proinflammatory cytokines, diverse effector molecules including growth factor, chemokines, eicosanoids and antimicrobial peptides are released from keratinocytes and augment the inflammatory responses in psoriasis $[37,39,40]$. The regulation of growth in psoriatic keratinocytes is mainly controlled by various growth factors, including epidermal growth factor (EGF) and keratinocyte growth factor (KGF) [33]. The members of the EGF family such as TGF- $\alpha$ and amphiregulin modulate the growth of epidermal keratinocytes in an autocrine fashion [41]. In an experimental model, the overexpression of EGF and its receptor induces the psoriasis-like skin hyperplasia and inflammation [42]. In addition, the activation of the EGF receptor further induces the production of vascular endothelial growth factor in keratinocytes, suggesting a relevant role in the growth of epidermal keratinocytes and angiogenesis observed in psoriasis [43]. Expression of KGF 
was recently observed in the lesional epidermal skin of a patient with psoriasis [44]. In a recent study, the expression of the KGF receptor was positively correlated with the degree of proliferation of $\mathrm{HaCa}$ $T$ keratinocytes [45]. KGF also promotes the expression of $\alpha 5 \beta 1$ integrin and inhibits the expression of K10 in keratinocytes [46]. Concerning chemokines, production of diverse chemokines from epidermal keratinocytes might considerably affect the activation of inflammatory cells in psoriasis. For example, chemokines like MIG/CXCL9, IL-10/CXCL10, IL-8/CXCL8, MCP-1/CCL2 and MIP-3 $\alpha$ /CCL20 released from epidermal keratinocytes function as potent chemoattractants for monocytes, neutrophils, Langerhans cells, DCs and T cells, which are key cells in psoriasis [31,47]. Moreover, non-lesional skin of the patients with psoriasis also releases keratinocyte-derived factors such as extra domain A-positive fibronectin; thereby, keratinocyte could modulate the autocrine circuit resulting in the epidermal hyperplasia in psoriasis [33]. All of these observations demonstrated that the psoriatic keratinocytes exert a great influence on the regulation of inflammatory cascade in psoriasis, and unraveling the complex immunologic circuits in psoriatic skin merit further investigations.

\subsubsection{Other Skin-Resident Immune Cells in Psoriasis}

Skin is also a sentinel for the immune system. The major role of skin as a peripheral lymphoid organ has been determined due to skin-associated lymphoid tissues [48]. Circulating skin-homing T cells express cutaneous lymphoid antigen and chemokine receptor (CCR)4, CCR6 and CCR10 [49,50]. However, the vast majority of cutaneous lymphoid antigen-positive $\mathrm{T}$ cells are residents of normal skin [51]. In addition to skin-homing T cells, other cells, including natural killer (NK) cells, natural killer T, DCs and Langerhans cells, are also found in normal skin [50,52,53]. A mouse model in which symptomless psoriatic skin was engrafted in severely immunodeficient mice lacking functional NK cells, T cells or B cells revealed the spontaneous production of psoriatic skin lesions, suggesting that tissue-resident immune cells themselves can be a major source for the development of psoriasis [54]. However, some researchers have argued that the aforementioned mouse model cannot fully represent a psoriatic model as it is not proper for evaluating the properties of leukocyte recruitment in psoriasis [50]. Moreover, patients with psoriasis treated with allogeneic bone marrow transplantation show resolution of their skin lesions, implying that not only skin-resident immune cells, but also systemic immune cells are important for the development and maintenance of psoriasis [55].

\section{Major Signal Transduction Pathway Alterations in Psoriasis}

The signal transduction pathway is another key regulator of various immune and inflammatory disorders and is involved by adjusted proliferation, differentiation and apoptosis of the cells. The complex nature of psoriasis pathogenesis can also be explained by altered signal transduction pathways. To date, altered signal transduction pathways have been observed in psoriasis including nuclear factor-kappa B (NF-kB), Janus kinase-signal transducers and activators of transcription (JAK-STAT), Akt and Wnt pathways. The dysregulation in these pathways influences the activation and trafficking of immune cells. In addition, these signal transduction pathways also regulate the survival, proliferation and differentiation of keratinocytes in psoriasis. Various studies have confirmed the dysregulation of signal transduction pathways in psoriasis using in vitro analyses, animal models and genomic analyses, as well as psoriatic lesional skin biopsies. In this section, the current knowledge of major signal transduction pathways involved in the pathogenesis of psoriasis will be discussed.

\subsection{NF- $\kappa B$ Signaling Pathways}

The activated form of NF- $\mathrm{kB}$ is a heterodimeric transcription factor composed of the $\mathrm{p} 65$ and p50 subunits [56]. After I $\kappa B$ kinase induces the detachment of NF- $\kappa B$ from I $\kappa B, N F-\kappa B$ enters the nucleus and affects specific sequences of target genes [56]. Various stimuli can activate NF- $k B$ signaling pathways; these include TNF- $\alpha$, IL-1, IL-17, virus and lipopolysaccharide [57]. In psoriasis, expression of NF- $\mathrm{kB}$ is upregulated in the psoriatic skin compared to healthy controls [58]. As a pivotal element for regulating the inflammatory process, NF- $\mathrm{KB}$ can modulate the transcription of 
various cytokines, chemokines, adhesion molecules and enzymes. It also affects the production of inflammatory cytokines such as TNF- $\alpha$, IL-1, IL-6 and IL-8 (Figure 2A). In addition, NF- $\mathrm{kB}$ activation can affect the differentiation and proliferation of keratinocytes in psoriatic skin [59].

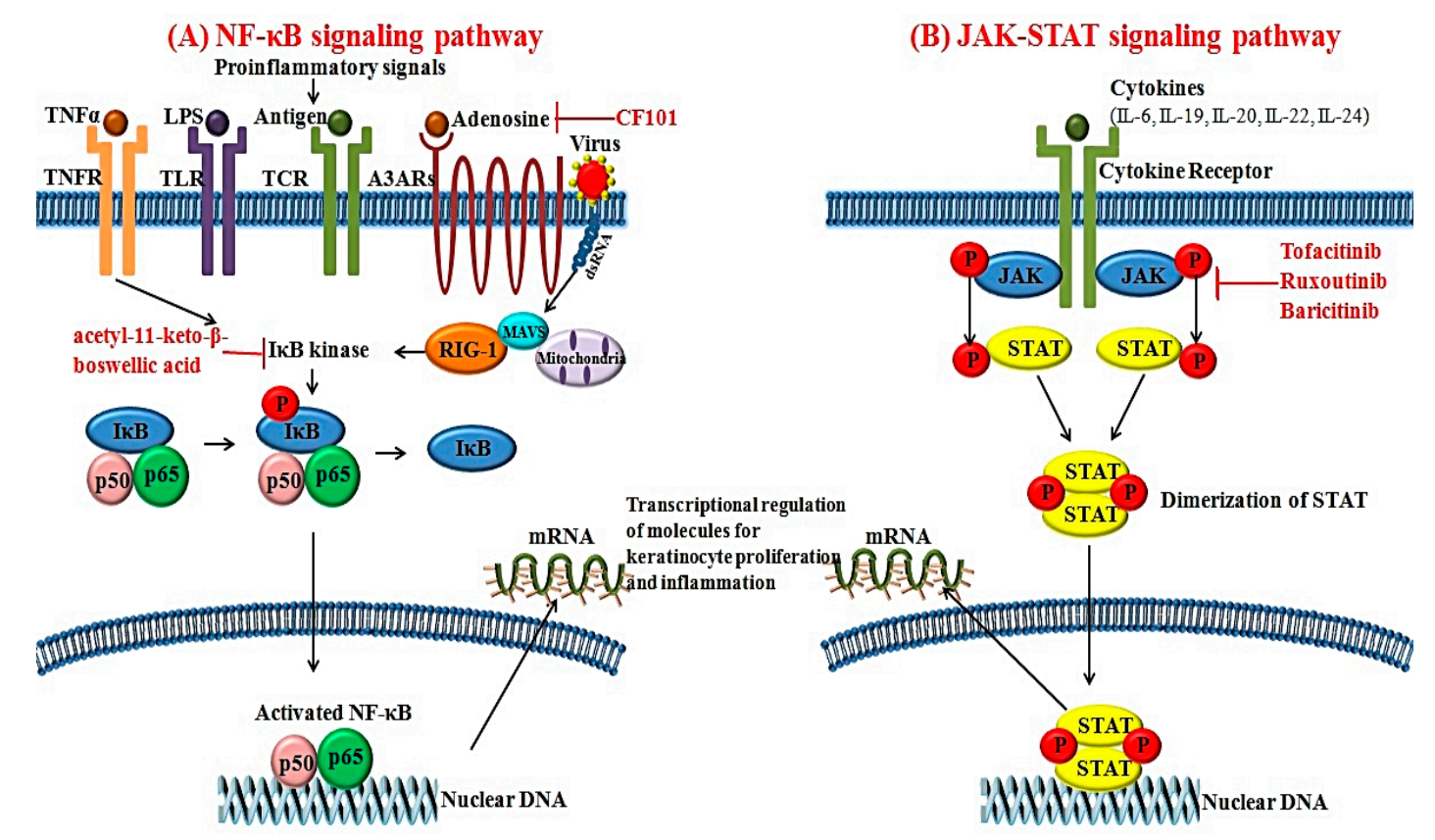

Figure 2. Schematic view of (A) the NF- $\kappa$ B signaling pathway and (B) the JAK-STAT signaling pathway that contribute to the pathogenesis of psoriasis and its novel targeting molecules. T-bar implies inhibition; The circled P represents phosphorylation; NF, nuclear factor $\mathrm{KB}$; $\mathrm{TNF}$, tumor necrosis factor; LPS, lipopolysaccharide; TLR, toll-like receptor; TCR, T-cell receptor; A3AR, A3 adenosine receptor; RIG-1, retinoic acid inducible-gene 1; JAK, Janus kinase; STAT, signal transducers and activators of transcription.

Recently, increased expression of retinoic acid inducible-gene 1 (RIG-1) was reported in psoriatic skin lesions [60]. RIG-1 is a major sensor for RNA viruses and activates NF- $k B$ signaling pathways [60]. Elevated expression of RIG-1 has also been observed in IL-23 and an imiquimod-induced mouse model of psoriasis [60]. RIG-1-deficient mice show lower degrees of epidermal hyperplasia and inflammatory cell infiltration. The gene that encodes RIG-1 is DDX58, a well-known susceptibility gene for psoriasis [61]. Zhu et al. [60] have found that activation of NF-kB signaling pathways via RIG-1 is associated with the production of IL-23 in DCs in psoriasis. Based on these findings, RIG-1 could be another novel target for managing inflammation and keratinocyte hyperproliferation in psoriasis.

\subsection{JAK-STAT Signaling Pathways}

JAK is a cytoplasmic tyrosine kinase important for inducing cytokine-associated signaling pathways [11]. To date, four subtypes of JAKs have been identified: JAK1, JAK2, JAK3 and tyrosine kinase 2 [11]. Activation of JAK can be initiated by various cytokines and growth factors. Activated JAK will phosphorylate STAT. Therefore, JAK has effects on both the signal transducer and transcription factor (Figure 2B) [62]. Among the various STATs, STAT3 can modulate cellular proliferation, differentiation and apoptosis. Cytokines including IL-6, -19, -20,-22 and -24 have been implicated in the pathogenesis of psoriasis and can initiate the activation of STAT3 [63]. In fact, STAT3 expression is upregulated in the psoriatic skin lesions compared to healthy controls [64]. Moreover, transgenic mice overexpressing active STAT3 cDNA can exhibit spontaneous psoriatic skin lesions [64]. 


\section{Genetics}

Genetic studies for psoriasis have offered pivotal pathogenic insights regarding psoriasis pathogenesis. The earlier case-control studies have been conducted to identify the genetic association between major histocompatibility complex (MHC) and psoriasis [65-67]. Tiilikainen et al. [67] found that the prevalence of HLA-Cw6 was $45.9 \%$ in patients with psoriasis vulgaris and $7.4 \%$ in controls. A higher prevalence of human leukocyte antigen (HLA)-B13-positive cases among patients with psoriasis was observed compared to control phenotypes [68]. However, among diverse HLA alleles, specific HLA alleles alone are not adequate for the development of psoriasis, which could imply that other genes are involved in psoriasis pathogenesis [69].

To find out more specific candidate genes for psoriasis, classical linkage studies have been conducted. To date, 13 psoriasis susceptibility locus (PSORS)1-13 have been identified to be associated with psoriasis [70]. PSORS1 is located on chromosome 6p 21.3. It is the most frequently-replicated locus for psoriasis [71]. PSORS1 contains genes encoding HLA-C and corneodesmosin [72]. However, the possible occurrence of linkage disequilibrium across the suspected region caused the determination of specific disease susceptibility allele challenging. To better localize the psoriasis susceptibility locus, researchers used linkage disequilibrium mapping. For example, linkage disequilibrium mapping revealed that the PSORS1 is located in the proximity of HLA-C, which could cause the narrowing of the critical interval for the psoriasis susceptibility gene [73-75]. For other PSORS, PSORS2 on chromosome 17q25.3 has been found to contain genes encoding CARD14, SLC9A3R1, NAT9, RAPTOR and TBCD [76,77], while PSORS4 on 1q21.3 has been found to be located within the epidermal differentiation complex (EDC) which contains Loricrin, Filaggrin, Pglyrp and S100 genes [78]. However, many other PSORS found from linkage analyses have not been replicated, except for PSORS1, PSORS2 and PSORS4 [71].

With the development of genome-wide association studies (GWAS), specific alleles associated with a disease could be easily identified. In a GWAS study, markers for millions of single nucleotide polymorphisms are analyzed for their allelic differences between cases and controls [71]. Recently, various large-scale GWASs for psoriasis have identified possible risk factors for psoriasis (Table 1). The susceptibility loci for psoriasis contain many genes associated with disease pathogenesis such as genes involved in antigen presentation, Th1 cell differentiation, Th17 cell differentiation, nuclear factor $\mathrm{\kappa B}(\mathrm{NF}-\mathrm{kB})$ signaling, IFN signaling and keratinocyte proliferation. In relation to adaptive immunity, the genetic locus that provides the strongest association for psoriasis susceptibility is MHC class I $[79,80]$. Among MHC molecules, HLA-Cw6 on 6p 21.3 provides the strongest association with psoriasis $[81,82]$. Endoplasmic reticulum aminopeptidase 1 (ERAP1) is another well-known gene associated with the genetic risk locus for psoriasis [83]. ERAP protein functions as a peptidase that modulates the binding of peptides to the MHC class 1 molecule [71]. Genetic variants of ERAP1 alleles can affect their interactions with HLA-Cw6 [83]. This provides further insights into the pathogenesis of psoriasis resulting from genetic variants related to antigen presentation to an adaptive immune system. In addition, RUNX3 has been found to be associated with T helper (Th) 1 cell differentiation in psoriasis [84,85]. Moreover, SOC1, IL-12B, IL-23R, TRAF3IP2 and IL23A have been found to be related to the pathway involved in Th17 cell differentiation in psoriasis [79,86-88]. The role of innate immunity in the pathogenesis of psoriasis has been increasingly emphasized [89], and genetic variants associated with psoriasis have been increasingly explored. Genes IFIH1, DDX58, RNF114, IL-28RA, TYK2, EXOC2 and ELMO1 have been found to be involved in IFN-mediated antiviral pathway of psoriasis [61,83,90-93]. Genes CARD14, REL, TNIP1/ANXA6, TNFAIP3, UBE2L3, CARM1, NFKBIA and FBXL19 have been revealed to be involved in the NF- $\mathrm{KB}$ signaling pathway of psoriasis $[61,84,89,91,94-97]$. Recently, the largest meta-analysis of GWAS for psoriasis has identified 16 novel genetic loci for psoriasis [94], including CHUK on chromosome 10q24.31, FASLG on chromosome 1q24.3 and IKBKE on chromosome 1q32.1, which are associated with the NF- $\mathrm{KB}$ signaling pathway. In addition, genes for regulation of the skin barrier within EDC have been proven to be associated with psoriasis. A recent GWAS in the Chinese population found a relationship between psoriasis and SNPs 
in the LCE gene cluster [98]. Moreover, De Cid et al. have revealed that deletion of LCE3B and LCE3C is associated with higher risk for psoriasis in the European population [99].

Table 1. Genetic loci for psoriasis susceptibility.

\begin{tabular}{|c|c|c|c|c|}
\hline Gene Loci & Chromosomal Locus & SNP & Function of the Protein & Reference \\
\hline \multicolumn{5}{|c|}{ Antigen presentation } \\
\hline HLA-C & $6 \mathrm{p} 21$ & rs12191877 & Antigen presentation; MHC class I & [74] \\
\hline ERAP1 & $5 q 15$ & rs27432 & $\begin{array}{l}\text { Peptidase to trim peptides for binding } \\
\text { to MHC } 1 \text { antigen presentation }\end{array}$ & [83] \\
\hline \multicolumn{5}{|c|}{ Th1 or Th17 cell differentiation/regulation } \\
\hline RUNX3 & $1 \mathrm{p} 36$ & rs7536201 & $\begin{array}{l}\text { Transcription factor regulating Th1 } \\
\text { and memory T-cell differentiation }\end{array}$ & [84] \\
\hline SOCS1 & $16 \mathrm{p} 13$ & rs367569 & Th17 cell differentiation & [86] \\
\hline$I L-12 B$ & $5 q 31$ & $\begin{array}{l}\text { rs4379175 } \\
\text { rs3213094 }\end{array}$ & $\begin{array}{l}\text { Encoding p40 subunit of IL- } 23 \text { and } \\
\text { IL-12 and promoting Th1 cell } \\
\text { differentiation }\end{array}$ & {$[87,100]$} \\
\hline$I L-23 R$ & $1 \mathrm{p} 31$ & $\begin{array}{l}\text { rs2201841 } \\
\text { rs11209026 }\end{array}$ & $\begin{array}{c}\text { Encoding IL-23 receptor subunit and } \\
\text { inducing TNF } \alpha \text {-dependent epidermal } \\
\text { hyperplasia }\end{array}$ & {$[88,91]$} \\
\hline TRAF3IP2 & $6 \mathrm{q} 21$ & $\begin{array}{l}\text { rs13210248, } \\
\text { rs33980500 }\end{array}$ & $\begin{array}{l}\text { Modulation of IL-17 signaling and } \\
\text { affects the NF- } \mathrm{k} \text { B signaling }\end{array}$ & [79] \\
\hline IL23A & $12 \mathrm{q} 13$ & rs2066808 & Encoding p19 subunit of IL-23 & [88] \\
\hline \multicolumn{5}{|c|}{ NF- $\kappa B$ signaling } \\
\hline CARD14 & $17 q 25$ & rs11652075 & Activation of NF- $\mathrm{kB}$ signaling & [94] \\
\hline$R E L$ & 2 p16 & rs702873 & Involved in NF- $\mathrm{KB}$ signaling & [95] \\
\hline TNIP1/ANXA6 & $5 \mathrm{q} 33$ & rs2233278 & Modulation of NF- $\mathrm{kB}$ signaling & [96] \\
\hline TNFAIP3 & $6 \mathrm{q} 23$ & rs610604 & Modulation of NF-KB signaling & [88] \\
\hline UBE2L3 & $22 \mathrm{q} 11$ & rs4821124 & Regulating NF- $\mathrm{kB}$ signaling & [84] \\
\hline CARM1 & $19 \mathrm{p} 13$ & $\mathrm{~N} / \mathrm{A}$ & Coactivator for NF-kB signaling & [61] \\
\hline NFKBIA & $14 \mathrm{q} 13$ & rs8016947 & Inhibition of NF- $\mathrm{kB}$ signaling & [91] \\
\hline FBXL19 & 16 p11 & rs12445568 & Inhibition of NF- $\mathrm{KB}$ signaling & [97] \\
\hline \multicolumn{5}{|c|}{ IFN signaling } \\
\hline IFIH1 & $2 q 24$ & rs17716942 & RIG-like helicase; antiviral receptor & [90] \\
\hline DDX58 & $9 \mathrm{p} 12$ & rs11795343 & Innate RIG-1 antiviral signaling & [61] \\
\hline RNF114 & $20 \mathrm{q} 13$ & rs1056198 & $\begin{array}{c}\text { Innate antiviral signaling; E3 } \\
\text { ubiquitin ligase }\end{array}$ & [91] \\
\hline$I L-28 R A$ & $1 \mathrm{p} 36$ & rs4649203 & IFN signaling, IL-29 receptor subunit & [92] \\
\hline TYK2 & $19 \mathrm{p} 13$ & rs 12720356 & Involved in IFN signaling & [83] \\
\hline EXOC2 & $6 \mathrm{p} 25$ & rs9504361 & $\begin{array}{l}\text { Promotes production of type } 1 \text { IFNs } \\
\text { in response to intracellular DNA }\end{array}$ & [93] \\
\hline ELMO1 & $7 \mathrm{p} 14$ & rs2700987 & $\begin{array}{l}\text { Enhances toll like receptor mediated } \\
\text { IFN- } \alpha \text { production }\end{array}$ & [93] \\
\hline \multicolumn{5}{|c|}{ Epidermal keratinocytes } \\
\hline$L C E 3 B / L C E 3 C$ & $1 \mathrm{q} 21$ & rs6677595 & Structural protein for keratinocytes & [101] \\
\hline$L C E 3 D$ & $1 \mathrm{q} 21$ & rs4112788 & $\begin{array}{l}\text { Regulates terminal differentiation of } \\
\text { epidermal keratinocytes }\end{array}$ & [91] \\
\hline LCE1C & $1 \mathrm{q} 21$ & rs6701216 & Structural protein for keratinocytes & [98] \\
\hline GJB2 & $13 \mathrm{q} 12$ & rs3751385 & Connexin 26 & [102] \\
\hline
\end{tabular}

Although GWAS studies can be exerted as a potent tool for identifying the association between genes and psoriasis, there are some potential limitations. Rare genetic variations are difficult to detect through GWAS studies [103]. Moreover, the possibility of the occurrence of linkage disequilibrium and population stratification might bias the experimental results [104]. With the advent of next generation sequencing, recognition of rare alleles can be more easily investigated than before. Recently, Tang et al. [103] explored the single nucleotide variants associated with psoriasis in GJB2, IL23R, ERAP1, LCE3D, ERAP1, ZNF816A and CARD14 among the Han Chinese population by next generation sequencing. Further studies using next generation sequencing technology in psoriasis are needed and are expected to lead to the increased understanding of the genetics of psoriasis. 


\section{Epigenetics}

Dysregulation in the epigenetic network has been suggested to be one possible pathogenic factor in various autoimmune disorders, including atopic dermatitis, systemic lupus erythematosus, rheumatoid arthritis, systemic sclerosis and psoriasis [105]. In twin studies, the concordance rate in psoriasis among monozygotic twins has been found to be $36-64 \%$ [106,107]. Such discordance in monozygotic twins implies that epigenetic modification might also play an important role in the development of psoriasis. DNA methylation, histone modification and microRNA (miRNA) profile are the major three epigenetic modifications in psoriasis. The emerging role of epigenetic modifications in psoriasis will be described below.

\subsection{DNA Methylation}

DNA methylation in psoriasis occurs both in lesional skin of psoriasis and peripheral blood mononuclear cells (PBMCs). Furthermore, it regulates the gene expression [108]. DNA methylation frequently occurs in cytosine-guanine islands within gene promoter lesion [109]. Cytosine-guanine hypomethylation in p15/CDKN2B and p21/CDKN1A genes involved in cell cycling has been observed in mononuclear cells isolated from bone marrow of patients with psoriasis [110]. In addition, the number of highly-proliferative potential colony-forming cells in bone marrow of psoriasis patients is significantly decreased compared to that in the normal control group [110]. As psoriasis is characterized by prominent epidermal hyperproliferation, it has been supposed that keratinocytes in lesional skin samples of patients with psoriasis show resistance to programmed cell death [111]. The $\mathrm{p} 16^{\mathrm{INK} 4 \mathrm{a}}$ promoter region is as an anti-apoptotic molecule and was shown to be hypermethylated in $30 \%$ of psoriasis patients [112]. Psoriasis Area and Severity Index (PASI) scores were also elevated in patients with hypermethylation of $\mathrm{p} 16^{\mathrm{INK} 4 \mathrm{a}}$ [112]. Recently, Zong et al. [113] have reported that HLA-DRB1 is hypomethylated in lesional skin samples of patients with psoriasis and is negatively correlated with PASI scores.

\subsection{Histone Modification}

In addition to DNA methylation, histone modification, which occurs through acetylation, deacetylation, phosphorylation, ubiquitination, deamination or proline isomerization tag, is associated with psoriasis [114]. Acetylation and deacetylation of histone tails are regulated by histone acetyltransferases and histone deacetylases (HDACs) [115]. Hypoacetylation of global histone $\mathrm{H} 4$ has been observed in PBMCs of psoriasis patients compared to that in normal controls. In addition, the degree of hypomethylation is negatively correlated with PASI score [115]. Moreover, overexpression of HDAC-1 mRNA has been observed in skin samples from psoriasis patients. It might cause overexpression of hypoxia inducible factor- $1 \alpha$ in hypoxic conditions [116]. Therefore, the HDAC inhibitor has emerged as a promising agent for controlling immune and inflammatory diseases, including psoriasis $[117,118]$.

\section{3. miRNAs}

Recently, various studies have been conducted to determine the role of miRNAs in the pathogenesis of inflammatory skin disorders such as atopic dermatitis [119] and psoriasis [120]. miR-125b regulates proliferation and differentiation of keratinocytes by regulating functions of fibroblast growth factor receptor 2. Downregulation of miR-125b has been observed in the lesional skin of patients with psoriasis and is negatively correlated with expression levels of fibroblast growth factor receptor 2 [121] and TNF- $\alpha$ [122]. In addition, expression of miR-146a has been found to be increased in lesional skin samples of patients with psoriasis. miR-146a modulates IL-17-associated skin inflammation in human skin and in a mouse model and is also involved in the TNF- $\alpha$ signaling pathway $[115,123,124]$. In a recent study, Hermann et al. [120] have found that miR-146b and miR-146a are overexpressed in lesional skin samples of patients with psoriasis. FERMT1 associated with 
keratinocyte hyperproliferation is the direct target gene for miR-146a [120]. Therefore, increased expression of miR-146a and miR-146b in psoriasis might be a mechanism underlying the proliferation of keratinocytes in psoriasis. Recently, Wang et al. [125] have reported that the miRNA axis is imbalanced in psoriasis. In addition to miR-146 and miR125b, the authors identified other miRNAs associated with psoriasis, including miR-31, miR-203 and has-miR-99a [125]. They suggested that increased expression of miR-31 and miR-203 with decreased expression of has-miR-99a and miR-125b might contribute to the imbalance in the miRNAs axis in psoriasis [125]. Indeed, various molecules associated with diverse miRNA modifications in psoriasis have been identified. Key miRNAs associated with psoriasis are summarized in Table 2. Further studies are needed to reveal interconnected epigenetic modifications in psoriasis.

Table 2. Various microRNAs with perturbed expression in psoriasis.

\begin{tabular}{|c|c|c|c|c|}
\hline miRNAs & Expression & Target Genes & Possible Mechanism of Action on Psoriasis & References \\
\hline miR-21 & Upregulated & $\begin{array}{l}\text { TIMP3, } \\
\text { TACE/ADAM17 }\end{array}$ & $\begin{array}{l}\text { Activation of TNF- } \alpha \text { signaling, suppression of } \\
\text { apoptosis in activated T cells }\end{array}$ & {$[126,127]$} \\
\hline miR-31 & Upregulated & $\begin{array}{l}\text { STK40, FIH-1, } \\
\text { ppp6c, EMP-1 }\end{array}$ & $\begin{array}{l}\text { Proliferation and differentiation of keratinocytes } \\
\text { Modulation of TGF- } \beta 1 \text { and NF- } \mathrm{kB} \text { signaling }\end{array}$ & [128-130] \\
\hline miR-136 & Upregulated & $P P P 2 R 2 A$ & $\begin{array}{l}\text { Modulation of TGF- } \beta 1 \text {-associated keratinocyte } \\
\text { proliferation arrest }\end{array}$ & [131] \\
\hline miR-143 & Upregulated & SLC26A4 & $\begin{array}{l}\text { Recruitment of neutrophils and monocytes from } \\
\text { peripheral blood }\end{array}$ & [132] \\
\hline miR-146 & Upregulated & EGFR, FERMT1 & Keratinocyte proliferation & {$[120,133]$} \\
\hline miR-155 & Upregulated & CTLA-4 & $\begin{array}{l}\text { Regulation of } \mathrm{T} \text { cell activation, involved in } \\
\text { development of dendritic cells and Treg cells }\end{array}$ & {$[134,135]$} \\
\hline miR-203 & Upregulated & $\begin{array}{l}\text { SOCS-3, STAT3, } \\
\text { SOSC-6 }\end{array}$ & $\begin{array}{l}\text { Suppression of SOCS-3-dependent signaling, } \\
\text { regulation of keratinocyte proliferation and } \\
\text { differentiation via STAT3 }\end{array}$ & {$[136,137]$} \\
\hline $\operatorname{miR}-221 / 2$ & Upregulated & TIMP3 & $\begin{array}{l}\text { Degradation of TIMP3, regulation of } \\
\text { keratinocyte growth and apoptosis }\end{array}$ & [138] \\
\hline miR-223 & Upregulated & GLUL, SMAD3 & Modulation of leukocyte chemotaxis & [132] \\
\hline Has-miR-99a & Downregulated & IGF-1R & $\begin{array}{l}\text { Modulation of keratinocyte proliferation and } \\
\text { differentiation }\end{array}$ & {$[125,139]$} \\
\hline $\mathrm{miR}-125 \mathrm{~b}$ & Downregulated & FGFR2 & Modulation of keratinocyte proliferation & [121] \\
\hline miR-138 & Downregulated & RUNX3 & Modulation of Th1/Th2 balances on $\mathrm{CD} 4^{+} \mathrm{T}$ cells & [140] \\
\hline $\operatorname{miR}-424$ & Downregulated & MEK1, Cyclin E1 & $\begin{array}{l}\text { Modulation of MEK1 and cyclin E1 dependent } \\
\text { keratinocyte proliferation }\end{array}$ & [135] \\
\hline
\end{tabular}

\subsection{Long Noncoding RNA}

Long non-coding RNAs (lncRNAs) could be defined as non-protein coding transcripts that are longer than 200 nucleotides [141]. Recent studies found that the lncRNAs exert an important role in regulating the immune system by modifying gene expression in diverse inflammatory diseases such as systemic lupus erythematosus, rheumatoid arthritis and psoriasis [142-144]. The expression of lncRNA gene PRINS was elevated in the non-lesional skin of patients with psoriasis compared to the lesional skin of patients with psoriasis and healthy controls, implying that PRINS plays a role as a psoriasis susceptibility gene [144]. In addition, the other lncRNA gene, PSORS1C3, which resides within PSORS1, has been identified as an important psoriasis susceptibility gene in Swedish and Chinese populations $[145,146]$. Although various studies have been conducted to identify the association between inflammatory disorder and specific lncRNA genes, in fact, a small number of IncRNA genes has been found in psoriasis. Further studies are required to find more associated lncRNA genes and to identify possible interrelationships of these lncRNA genes with other epigenetic modifications in psoriasis. 


\section{Environmental Factors}

\subsection{Obesity}

A variety of epidemiological studies has identified the relationship between psoriasis and obesity. Wolk et al. [147] found that obese individuals have a greater risk of having psoriasis more than twice as much as healthy controls. Moreover, the prevalence and severity of psoriasis are positively correlated with the presence of obesity $[148,149]$. The adipose tissue itself functions as an important endocrine, paracrine and autocrine organ via various adipokines and inflammatory cytokines [148]. Moreover, the composition of adipose tissue is altered in obese people, which potentiates further proinflammatory responses [148]. Among various molecules, the major cytokines that are concurrently expressed in both adipose tissue and skin of patients with psoriasis are IL-6 and TNF- $\alpha$ [148]. The simultaneously increased expressions of inflammatory cytokines observed in both conditions might provide a potential link to the pathogenic mechanisms between obesity and psoriasis.

\subsection{Alcohol Consumption}

Alcohol is a potent environmental risk factor for psoriasis. Qureshi et al. [150] revealed that heavy alcohol consumption and development of psoriasis are positively correlated. Moreover, patients with moderate to severe psoriasis tend to have a more increased incidence of alcohol-related diseases such as depression and cardiovascular diseases [151]. The metabolites of alcohol increase the expression of soluble TNF-receptor type 1 and TNF- $\alpha$ converting enzyme, which are associated with propagating inflammation in psoriasis [152]. In addition, the effects of ethanol and acetone on $\mathrm{HaCa} T$ keratinocytes were explored in an in vitro model [153]. The proliferative response in $\mathrm{HaCa} \mathrm{T}$ cells was observed after treatment with acetone and ethanol [153], suggesting that alcohol consumption might affect the epidermal hyperproliferation observed in psoriasis.

\subsection{Psychological Stress}

Psychological stress also plays a potent role in the initiation and aggravation of psoriasis [154]. In patients with psoriasis, psychologically-stressful conditions resulted in the upregulation of sympathetic-adrenomedullary system and downregulation of the hypothalamus-pituitary-adrenal axis $[155,156]$. In these circumstances, decreased levels of cortisol and increased levels of epinephrine and norepinephrine can be observed in patients with psoriasis when compared with healthy controls [156]. The altered levels in these values in patients with psoriasis further leads to the degranulation of mast cells, alteration in skin barrier function and the release of proinflammatory cytokines, all of which are associated with the pathogenesis of psoriasis [157]. Moreover, patients with psoriasis suffer from stress due to the disease itself, which can cause a chronic disfiguring appearance of the patient [155]. Interrupting this vicious cycle might be helpful in managing patients with psoriasis.

\subsection{Tobacco Smoking}

Cigarettes contain many toxic molecules. In relation to epigenetic modification, tobacco smoking is associated with differential DNA methylation [158]. For patients with psoriasis, tobacco exposure is associated with methylation of $\mathrm{p} 16^{\mathrm{INH} 4 a}$ [159]. Torri et al. [160] have reported that the number of Th17 cells is increased in PBMCs of smokers compared to non-smokers. Tobacco smoke extract can induce Th17 differentiation and expression levels of IL-17 and IL-22, which are cytokines associated with the pathogenesis of psoriasis, in an in vitro analysis [160]. In addition, nicotinic acetylcholine receptors can modulate the function of keratinocytes through the signaling pathway [161]. Besides their expression in keratinocytes, nicotinic acetylcholine receptors are expressed in diverse immune cells, including T cells and leukemic cell lines [161], thereby nicotine exposure from tobacco smoking could disturb the immune system in patients with psoriasis. 


\subsection{Vitamin D}

Vitamin D plays an important role in numerous inflammatory cutaneous disorders, including atopic dermatitis, chronic urticaria and rosacea [162-164]. Indeed, decreased serum levels of vitamin $\mathrm{D}$ in patients with psoriasis have been frequently observed [165]. The active form of vitamin D acts as a main regulator of the skin by regulating apoptosis, proliferation and differentiation of keratinocytes [166]. Moreover, vitamin D has regulatory effects on the proliferation of $\mathrm{T}$ cells and stimulatory effects on the propagation of Treg cells [166]. The topical formulation of vitamin D is the first line of therapies in psoriasis. Besides its anti-inflammatory effects, topical vitamin D might have therapeutic effects on psoriasis by inhibiting keratinocyte proliferation through the vitamin $\mathrm{D}$ receptor-associated genomic pathway and by stimulating keratinocyte differentiation via elevating intracellular calcium levels through a non-genomic pathway $[166,167]$.

\section{Novel Paradigm in Treatment Targets for Psoriasis}

To date, a variety of treatment options is available in managing psoriasis. In general, treatment of psoriasis is based on the severity of psoriasis. The topical therapies including keratolytic, anthralin, topical steroid, vitamin D analogs and calcineurin inhibitor are used to treat the mild form of psoriasis. In patients with moderate to severe psoriasis, phototherapy or systemic therapy including retinoid, cyclosporin, methotrexate and steroid can be used. However, some agents including topical steroid, phototherapy or cyclosporin might not be suitable for sustained long-term use to manage this chronic disorder. In addition, phototherapy or systemic therapy might not be successful in some patients with moderate to severe psoriasis. In these cases, targeting more specific pathways is required for more effective treatment. With the discoveries of major molecular targets in psoriasis, the clinical trials for several biologics and small molecules are currently investigating their efficacy and safety. In this section, a brief review of the novel targeted therapies in psoriasis including anti-cytokine therapies and small molecules will be presented (Table 3).

Table 3. Summary of novel targeted therapies in psoriasis.

\begin{tabular}{|c|c|c|c|c|}
\hline Targets & Drug & Mode of Action & $\begin{array}{l}\text { Route of } \\
\text { Administration }\end{array}$ & Ref. \\
\hline \multicolumn{5}{|c|}{ Biologics } \\
\hline \multirow{5}{*}{ TNF- $\alpha$} & Infliximab & Chimeric anti-TNF- $\alpha \mathrm{mAb}$ & IV & [74] \\
\hline & Adalimumab & Fully human anti-TNF- $\alpha$ mAb & SC & [83] \\
\hline & Etanercept & Human soluble TNF- $\alpha$ receptor & SC & [168] \\
\hline & Golimumab & Fully human anti-TNF- $\alpha$ mAb & SC & [169] \\
\hline & Certolizumab pegol & $\begin{array}{l}\text { Humanized PEGylated antigen binding } \\
\text { fragment of anti-TNF- } \alpha \mathrm{mAb}\end{array}$ & SC & [170] \\
\hline IL-12/23 & Ustekinumab & Fully human anti-IL-12/23 p40 mAb & SC & {$[171,172]$} \\
\hline \multirow{3}{*}{ IL-23 } & Tildrakizumab & Fully human IgG1 anti-IL-23 p19 mAb & SC & [173] \\
\hline & Guselkumab & Fully human IgG1 anti-IL-23 p19 mAb & SC & [174] \\
\hline & Risankizumab & Fully human anti-IL-23 p19 mAb & SC & [175] \\
\hline \multirow{5}{*}{ IL-17 } & Ixekizumab & Humanized IgG4 anti-IL-17 mAb & SC or IV & [176] \\
\hline & Secukinumab & Fully human IgG1 $\mathrm{\kappa}$ anti-IL-17 mAb & SC or IV & [177] \\
\hline & Brodalumab & Fully human IgG2 anti-IL-17 receptor mAb & SC & [171] \\
\hline & Ruxolitinib & Selective inhibitor of JAK1 and JAK2 & Topical & [178] \\
\hline & Baricitinib & Selective inhibitor of JAK1 and JAK2 & Oral & [179] \\
\hline A3AR & CF101 & High affinity agonist for A3AR & Oral & [180] \\
\hline IкB kinase & $\begin{array}{l}\text { Acetyl-11-keto- } \\
\beta \text {-boswellic acid }\end{array}$ & I $\mathrm{KB}$ kinase inhibitor & Topical & [181] \\
\hline \multicolumn{5}{|c|}{ Small molecules } \\
\hline JAK & Tofacitinib & Selective inhibitor of JAK1 and JAK3 & $\begin{array}{l}\text { Oral, } \\
\text { Topical }\end{array}$ & [182] \\
\hline
\end{tabular}

Abbreviation: Ref., reference; TNF, tumor necrosis factor; mAb, monoclonal antibody; IV, intravenous; SC, subcutaneous; IL, interleukin; Ig, immunoglobulin; JAK, Janus kinase; A3AR, A3 adenosine receptor. 


\subsection{Anti-Cytokine Therapies for Psoriasis}

\subsubsection{Anti-TNF Therapy}

TNF therapies have long been established for the treatment of various inflammatory disorders, including rheumatoid arthritis, ankylosing spondylitis, inflammatory bowel disease and psoriasis [183]. Among the various anti-TNF agents used in psoriasis, infliximab is a chimeric monoclonal antibody with high affinity, specificity and avidity for TNF- $\alpha$ [184]. In a phase III study for infliximab, about $80 \%$ of patients with moderate to severe psoriasis achieved PASI 75 by Week 6 . By Week $50,61 \%$ of these patients maintained PASI 75 [185]. Etanercept, a fully human soluble TNF receptor fusion protein, lacks signaling domains, thereby neutralizing TNF- $\alpha$ [186]. Adalimumab and golimumab are also fully human recombinant immunoglobulin G1 monoclonal antibodies that specifically target TNF- $\alpha$. Golimumab has also been approved by the Food and Drug Administration to be used for psoriatic arthritis [169]. Recently, certolizumab pegol has been used in the treatment of psoriasis. Certolizumab pegol is a polyethylene glycol-conjugated humanized PEGylated antigen-binding fragment of the anti-TNF $\alpha$ monoclonal antibody. It lacks a fragment crystallizable (Fc) region. Therefore, it does not provoke an antibody-dependent cytotoxic reaction or complement activation found in other TNF $\alpha$ blockers [170]. PASI 75 was achieved in $83 \%$ of patients with moderate-severe psoriasis treated with $400 \mathrm{mg}$ certolizumab pegol [170]. Although various clinical trial studies for these aforementioned anti-TNF $\alpha$ agents have shown favorable response rates in psoriasis, like other biologics, treatment efficacies of various anti-TNF $\alpha$ agents in psoriasis have only been demonstrated in meta-analyses. These agents were compared indirectly. Therefore, diverse head-to-head studies comparing treatment efficacies of anti-TNF $\alpha$ agents in psoriasis need to be conducted in the future.

\subsubsection{IL-12/23 Inhibitors}

IL-12 and IL-23 share the same p40 subunit that binds to cell surface receptor IL-12R $\beta 1$. Ustekinumab is a human monoclonal anti-p40 antibody that binds to the p40 subunit of IL-12 and IL-23, thereby disturbing IL-12- and IL-23-mediated cell signaling [172]. The clinical efficacy of ustekinumab in psoriasis is well known. A long-term safety study reported that the use of ustekinumab for five years in psoriasis does not increase dose-related or cumulative toxicity in patients with psoriasis [172]. Puig et al. [187] have studied the treatment efficacy among different biologics in patients with moderate to severe psoriasis and found that ustekinumab has the most favorable effects compared to adalimumab, infliximab and etanercept. Recently, the more important role of IL-23 than IL-12 for Th17 cell differentiation and survival has been accumulated. IL-23 is a heterodimer consisting of the p40 subunit, which is also observed in IL-12, and p19, distinctive for IL-23 [188]. Therefore, many types of research are selectively targeting the IL-23 p19 subunit in psoriasis. Tildrakizumab is a humanized immunoglobulin G1 monoclonal antibody targeting the IL-23 p19 subunit [173]. A phase II study of $200 \mathrm{mg}$ tildrakizumab on psoriasis found that PASI 75 was achieved in $74.4 \%$ of the patients at Week 16. In addition, its treatment effect remained up to Week 52 [173]. The therapeutic potential of guselkumab, another fully human immunoglobulin G1 monoclonal antibody targeting the IL-23 p19 subunit, was tested in a recent phase III trial with $70 \%$ of patients achieving PASI 90 at Week 16 [174]. Another recent phase II trial study for risankizumab, a human immunoglobulin monoclonal antibody that selectively targets IL-23A, found that $77 \%$ of patients achieve PASI 90 after treatment with risankizumab compared to $40 \%$ of patients achieving PASI 90 after treatment with ustekinumab by Week 12 [175].

\subsubsection{IL-17 Inhibitor}

Diverse IL-17 inhibitors are now under investigation in psoriasis. Secukinumab is a fully human immunoglobulin G1k monoclonal antibody, while ixekizumab is a humanized immunoglobulin G4 monoclonal antibody. Both effectively neutralize IL-17A [176,177]. Brodalumab inhibits the IL-17-mediated signaling pathway in a slightly different way compared to the two aforementioned 
IL-17 inhibitors. Brodalumab is a human immunoglobulin G2 monoclonal antibody that can directly bind to the IL-17 receptor. It functions as an antagonist to the receptor and blocks signaling of IL-17A and IL-17F. Recently, a phase III study has been conducted to compare the clinical efficacies of brodalumab and ustekinumab [171]. Patients with moderate-to-severe psoriasis treated with brodalumab are found to have superior clinical efficacy for PASI 75 than those treated with ustekinumab [171]. Moreover, RG7624, an antibody targeting both IL-17A and IL-17F, has been reported for chronic inflammation [189]. However, no clinical trials have been conducted for this antibody targeting IL-17.

\subsection{Targeting Small Molecules for Psoriasis}

\subsubsection{JAK Inhibitors}

In psoriasis, JAK inhibitors have emerged as promising targets for psoriasis with favorable treatment outcomes. Topical application of JAK inhibitors can inhibit lymphocyte infiltration, STAT3 phosphorylation and keratinocyte proliferation in a mouse model of contact hypersensitivity [190]. Tofacitinib is a dual inhibitor for JAK1 and JAK3. Its efficacies for diverse inflammatory disorders, including inflammatory bowel disease and psoriasis, have been recently reported. Papp et al. [182] reported that $68.8 \%$ of patients with psoriasis treated with oral $10 \mathrm{mg}$ tofacitinib twice daily achieved PASI 75 at Week 28. Recently, another JAK inhibitor, ruxolitinib, was tested for psoriasis treatment. Topical application of ruxolitinib decreased the mean total lesion score in psoriasis [178]. The efficacy of baricitinib, a novel oral selective inhibitor for JAK1 and JAK2, on psoriasis was explored in a recent phase II trial with favorable results [179]. With the phase III study of baricitinib in the future, this molecule could be added as one effective novel agent for managing psoriasis.

\subsubsection{A3 Adenosine Receptor Agonists}

A3 adenosine receptor (A3AR) is a G-protein coupled receptor regulating various intracellular signaling pathways [191]. Increased expression of A3AR has been observed in lesional inflammatory cells and PBMCs in patients with chronic inflammatory disorders, including rheumatoid arthritis, Crohn's disease and psoriasis [191]. Inhibition of A3AR activation via A3AR agonist further downregulates the activation of NF- $\mathrm{kB}$ signaling pathways and promotes apoptosis of inflammatory cells [192]. CF101 is an orally-available high-affinity agonist for A3AR that exerts anti-inflammatory effects. A phase II clinical study for CF101 revealed that treatment with $2 \mathrm{mg}$ CF101 resulted in progressive improvement of PASI score in patients with moderate to severe plaque-type psoriasis compared to the placebo group [180].

\subsection{3. ІкB Kinase Inhibitor}

The NF- $\mathrm{KB}$ signaling pathway has been recently postulated as a novel target for the treatment of psoriasis. Treatment with acetyl-11-keto- $\beta$-boswellic acid, an inhibitor of IкB kinase, can improve psoriasis disease activity score [181]. In addition, TNF- $\alpha$ production regulated by the NF- $\mathrm{KB}$ signaling pathway is decreased after treatment with IкB kinase inhibitor acetyl-11-keto- $\beta$-boswellic acid in a psoriatic mice model [181]. Therefore, targeting NF- $\kappa B$ signaling pathway via inhibiting I $\kappa B$ kinase could be used as an important strategy to manage psoriasis.

\section{Discussion}

To date, many researchers have studied the molecular pathogenesis of psoriasis. The recent investigations for immunologic abnormalities in psoriasis have established the concept that the IL-23/Th17 axis is a key regulator of psoriasis. Besides T cells, diverse immunological abnormalities in cellular infiltration including keratinocytes, DCs and NK cells also play key roles in the initiation and maintenance of psoriasis (Figure 3). Imbalances in the immune system might allow the production of various inflammatory mediators and cofactors, which further affects inflammation and dysregulation 
in the differentiation and proliferation of keratinocytes via altered signaling pathways. Recent GWAS studies have identified various genetic components of psoriasis affecting the immune system and epidermal keratinocytes more specifically. In addition to the genetic component, the important role of epigenetic modifications in psoriasis is being currently emphasized. The interplay between genetic predisposition and epigenetic modification along with various environmental triggering factors might affect the development and persistence of psoriasis in susceptible patients. However, studies on genetic and epigenetic modifications in psoriasis are limited. Further investigations are needed to discover novel genetic risk loci and epigenetic modifications that contribute to the pathogenesis of psoriasis.

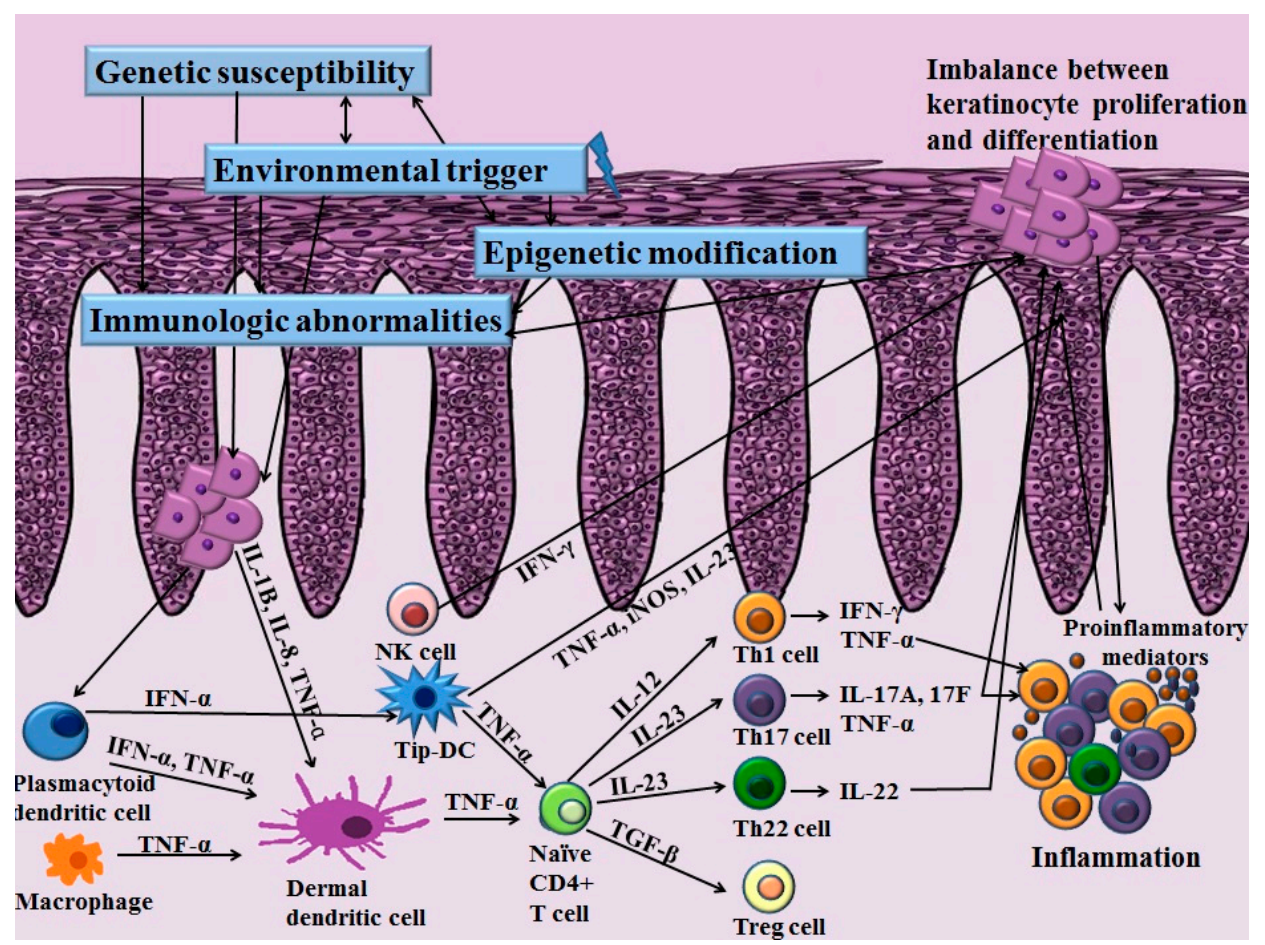

Figure 3. Schematic overview of effector immune cells and cytokines in the pathogenesis of psoriasis. In a genetically susceptible individual, environmental triggering factors along with epigenetic modifications affect dysregulated immune circuits in psoriasis. IFN- $\gamma$, interferon-gamma; Th, T helper cell; Treg, regulatory T cell; TGF- $\beta$, tumor growth factor-beta; TNF, tumor necrosis factor; IL, interleukin; iNOS, inducible nitric oxide synthase.

Previous management strategies for psoriasis have been focused on targeting T cells. However, many signs of progress have been made on psoriasis. The paradigm for psoriasis treatment has also shifted to targeting more specific cytokines such as TNF- $\alpha$, IL-17 and IL-23. As the use of these targeting molecules will gradually increase, careful attention should be continuously paid to those newly-approved targeted molecules for psoriasis regarding its efficacy and safety data.

In conclusion, the elucidation of molecular mechanisms and pathways involved in the pathogenesis of psoriasis has yielded promising results in the field of psoriasis. However, the complex linkage hidden behind each pathogenic pathway in regards to psoriasis susceptibility genes, epigenetic modification, environmental triggering factor and immune circuits needs to be integrated. Better understanding of immunological mechanisms regulating the interplay between immune cells and keratinocytes and the identification of more upstream and downstream key cytokines and their cellular sources in psoriasis can help to identify potential novel specific targets of psoriasis in the future. To manage the recurrence of psoriatic plaque in the same area even after the treatment, future studies should focus more on identifying and targeting skin-resident immune cells in psoriasis. The additional genetic phenotype studies estimating the treatment responses among various targets might bring 
more potential and novel tailored therapy to the patient. Thorough understanding of the molecular pathogenesis of psoriasis could bring promising results not only in the field of psoriasis, but also for other chronic inflammatory diseases that might possess similar cellular and molecular pathogenic networks in their pathogenesis.

Acknowledgments: This research was supported by the Basic Science Research program and Creative Materials Discovery Program through the National Research Foundation of Korea (NRF), which is funded by the Ministry of Education, Science and Technology and the Ministry of Science, ICT and Future Planning (2015R1C1A2A01055073, 2016M3D1A1021387).

Author Contributions: Yu Ri Woo wrote the manuscript. Dae Ho Cho conducted the review and rewrote the manuscript. Hyun Jeong Park contributed to the design, review and revision of the manuscript.

Conflicts of Interest: The authors declare no conflicts of interest.

\section{Abbreviations}

$\begin{array}{ll}\text { A3AR } & \text { A3 adenosine receptor } \\ \text { CCR } & \text { Chemokine receptor } \\ \text { DC } & \text { Dendritic cell } \\ \text { EDC } & \text { Epidermal differentiation complex } \\ \text { EGF } & \text { Epidermal growth factor } \\ \text { ERAP1 } & \text { Endoplasmic reticulum aminopeptidase 1 } \\ \text { FoxP3 } & \text { Forkhead/winged helix transcription factor 3 } \\ \text { GWAS } & \text { Genome-wide association studies } \\ \text { HDAC } & \text { Histone acetyltransferases and histone deacetylase } \\ \text { HLA } & \text { Human leukocyte antigen } \\ \text { IFN } & \text { Interferon } \\ \text { IL } & \text { Interleukin } \\ \text { iNOS } & \text { Inducible nitric oxide synthase } \\ \text { JAK } & \text { Janus kinase } \\ \text { KGF } & \text { Keratinocyte growth factor } \\ \text { KIRs } & \text { Killer immunoglobulin-like receptors } \\ \text { LncRNA } & \text { Long noncoding RNA } \\ \text { MHC } & \text { Major histocompatibility complex } \\ \text { miRNA } & \text { MicroRNA } \\ \text { NF-kB } & \text { Nuclear factor-kappa B } \\ \text { NK } & \text { Natural killer } \\ \text { PASI } & \text { Psoriasis Area and Severity Index } \\ \text { PBMC } & \text { Peripheral blood mononuclear cells } \\ \text { pDC } & \text { Plasmacytoid dendritic cells } \\ \text { PGRP } & \text { Peptidoglycan recognition proteins } \\ \text { PSORS } & \text { Psoriasis susceptibility locus } \\ \text { RIG-1 } & \text { Retinoic acid inducible-gene 1 } \\ \text { STAT } & \text { Signal transducer and activator of transcription } \\ \text { Th } & \text { T helper } \\ \text { Treg } & \text { T regulatory } \\ \text { Tip-DC } & \text { TNF- } \alpha \text { and iNOS-producing DC } \\ \text { TNF } & \text { Tumor necrosis factor } \\ & \end{array}$

\section{References}

1. Naldi, L.; Gambini, D. The clinical spectrum of psoriasis. Clin. Dermatol. 2007, 25, 510-518. [CrossRef] [PubMed]

2. Parisi, R.; Symmons, D.P.; Griffiths, C.E.; Ashcroft, D.M. Global epidemiology of psoriasis: A systematic review of incidence and prevalence. J. Investig. Dermatol. 2013, 133, 377-385. [CrossRef] [PubMed] 
3. Enamandram, M.; Kimball, A.B. Psoriasis epidemiology: The interplay of genes and the environment. J. Investig. Dermatol. 2013, 133, 287-289. [CrossRef] [PubMed]

4. Jacob, S.E.; Nassiri, M.; Kerdel, F.A.; Vincek, V. Simultaneous measurement of multiple Th1 and Th2 serum cytokines in psoriasis and correlation with disease severity. Mediat. Inflamm. 2003, 12, 309-313. [CrossRef] [PubMed]

5. Coimbra, S.; Figueiredo, A.; Castro, E.; Rocha-Pereira, P.; Santos-Silva, A. The roles of cells and cytokines in the pathogenesis of psoriasis. Int. J. Dermatol. 2012, 51, 389-398. [CrossRef] [PubMed]

6. Harden, J.L.; Johnson-Huang, L.M.; Chamian, M.F.; Lee, E.; Pearce, T.; Leonardi, C.L.; Haider, A.; Lowes, M.A.; Krueger, J.G. Humanized anti-IFN- $\gamma(\mathrm{HuZAF})$ in the treatment of psoriasis. J. Allergy Clin. Immunol. 2015, 135, 553-556. [CrossRef] [PubMed]

7. Tonel, G.; Conrad, C.; Laggner, U.; di Meglio, P.; Grys, K.; McClanahan, T.K.; Blumenschein, W.M.; Qin, J.-Z.; Xin, H.; Oldham, E. Cutting edge: A critical functional role for IL-23 in psoriasis. J. Immunol. 2010, 185, 5688-5691. [CrossRef] [PubMed]

8. Girolomoni, G.; Strohal, R.; Puig, L.; Bachelez, H.; Barker, J.; Boehncke, W.; Prinz, J. The Role of IL-23 and the IL-23/TH17 Immune Axis in the Pathogenesis and Treatment of Psoriasis. J. Eur. Acad. Dermatol. Venereol. 2017, 31, 1616-1626. [CrossRef] [PubMed]

9. Chan, J.R.; Blumenschein, W.; Murphy, E.; Diveu, C.; Wiekowski, M.; Abbondanzo, S.; Lucian, L.; Geissler, R.; Brodie, S.; Kimball, A.B. IL-23 stimulates epidermal hyperplasia via TNF and IL-20R2-dependent mechanisms with implications for psoriasis pathogenesis. J. Exp. Med. 2006, 203, 2577-2587. [CrossRef] [PubMed]

10. Lynde, C.W.; Poulin, Y.; Vender, R.; Bourcier, M.; Khalil, S. Interleukin 17A: Toward a new understanding of psoriasis pathogenesis. J. Am. Acad. Dermatol. 2014, 71, 141-150. [CrossRef] [PubMed]

11. Kofoed, K.; Skov, L.; Zachariae, C. New drugs and treatment targets in psoriasis. Acta Derm. Venereol. 2015, 95, 133-139. [CrossRef] [PubMed]

12. Liang, S.C.; Tan, X.-Y.; Luxenberg, D.P.; Karim, R.; Dunussi-Joannopoulos, K.; Collins, M.; Fouser, L.A. Interleukin (IL)-22 and IL-17 are coexpressed by Th17 cells and cooperatively enhance expression of antimicrobial peptides. J. Exp. Med. 2006, 203, 2271-2279. [CrossRef] [PubMed]

13. Rizzo, H.L.; Kagami, S.; Phillips, K.G.; Kurtz, S.E.; Jacques, S.L.; Blauvelt, A. IL-23-Mediated Psoriasis-Like Epidermal Hyperplasia Is Dependent on IL-17A. J. Immunol. 2011, 186, 1495-1502. [CrossRef] [PubMed]

14. Teunissen, M.B.; Bos, J.D.; Koomen, C.W.; de Waal Malefyt, R.; Wierenga, E.A. Interleukin-17 and interferon- $\gamma$ synergize in the enhancement of proinflammatory cytokine production by human keratinocytes. J. Investig. Dermatol. 1998, 111, 645-649. [CrossRef] [PubMed]

15. Volpe, E.; Servant, N.; Zollinger, R.; Bogiatzi, S.I.; Hupé, P.; Barillot, E.; Soumelis, V. A critical function for transforming growth factor- $\beta$, interleukin 23 and proinflammatory cytokines in driving and modulating human TH-17 responses. Nat. Immunol. 2008, 9, 650-657. [CrossRef] [PubMed]

16. Oliveira, P.S.S.D.; Cardoso, P.R.G.; Lima, E.V.D.A.; Pereira, M.C.; Duarte, A.L.B.P.; Pitta, I.D.R.; Rêgo, M.J.B.D.M.; Pitta, M.G.D.R. IL-17A, IL-22, IL-6, and IL-21 serum levels in plaque-type psoriasis in Brazilian patients. Mediat. Inflamm. 2015, 2015, 819149. [CrossRef] [PubMed]

17. Deng, Y.; Chang, C.; Lu, Q. The inflammatory response in psoriasis: A comprehensive review. Clin. Rev. Allergy Immunol. 2016, 50, 377-389. [CrossRef] [PubMed]

18. Sa, S.M.; Valdez, P.A.; Wu, J.; Jung, K.; Zhong, F.; Hall, L.; Kasman, I.; Winer, J.; Modrusan, Z.; Danilenko, D.M. The effects of IL-20 subfamily cytokines on reconstituted human epidermis suggest potential roles in cutaneous innate defense and pathogenic adaptive immunity in psoriasis. J. Immunol. 2007, 178, 2229-2240. [CrossRef] [PubMed]

19. Zheng, Y.; Danilenko, D.M.; Valdez, P.; Kasman, I.; Eastham-Anderson, J.; Wu, J.; Ouyang, W. Interleukin-22, a TH17 cytokine, mediates IL-23-induced dermal inflammation and acanthosis. Nature 2007, 445, 648-651. [CrossRef] [PubMed]

20. Martin, J.C.; Wolk, K.; Bériou, G.; Abidi, A.; Witte-Händel, E.; Louvet, C.; Kokolakis, G.; Drujont, L.; Dumoutier, L.; Renauld, J.-C. Limited Presence of IL-22 Binding Protein, a Natural IL-22 Inhibitor, Strengthens Psoriatic Skin Inflammation. J. Immunol. 2017, 198, 3671-3678. [CrossRef] [PubMed]

21. Gaspari, A.A. Innate and adaptive immunity and the pathophysiology of psoriasis. J. Am. Acad. Dermatol. 2006, 54, S67-S80. [CrossRef] [PubMed] 
22. Ettehadi, P.; Greaves, M.; Wallach, D.; Aderka, D.; Camp, R. Elevated tumour necrosis factor- $\alpha$ (TNF- $\alpha)$ biological activity in psoriatic skin lesions. Clin. Exp. Immunol. 1994, 96, 146-151. [CrossRef] [PubMed]

23. Partsch, G.; Steiner, G.; Leeb, B.; Dunky, A.; Bröll, H.; Smolen, J. Highly increased levels of tumor necrosis factor- $\alpha$ and other proinflammatory cytokines in psoriatic arthritis synovial fluid. J. Rheumatol. 1997, 24, 518-523. [PubMed]

24. Zaba, L.C.; Cardinale, I.; Gilleaudeau, P.; Sullivan-Whalen, M.; Suárez-Fariñas, M.; Fuentes-Duculan, J.; Novitskaya, I.; Khatcherian, A.; Bluth, M.J.; Lowes, M.A. Amelioration of epidermal hyperplasia by TNF inhibition is associated with reduced Th17 responses. J. Exp. Med. 2007, 204, 3183-3194. [CrossRef] [PubMed]

25. Chiricozzi, A.; Guttman-Yassky, E.; Suárez-Farinas, M.; Nograles, K.E.; Tian, S.; Cardinale, I.; Chimenti, S.; Krueger, J.G. Integrative responses to IL-17 and TNF- $\alpha$ in human keratinocytes account for key inflammatory pathogenic circuits in psoriasis. J. Investig. Dermatol. 2011, 131, 677-687. [CrossRef] [PubMed]

26. Zhang, L.; Yang, X.-Q.; Cheng, J.; Hui, R.-S.; Gao, T.-W. Increased Th17 cells are accompanied by FoxP3+ Treg cell accumulation and correlated with psoriasis disease severity. Clin. Immunol. 2010, 135, $108-117$. [CrossRef] [PubMed]

27. Ehrenstein, M.R.; Evans, J.G.; Singh, A.; Moore, S.; Warnes, G.; Isenberg, D.A.; Mauri, C. Compromised function of regulatory $\mathrm{T}$ cells in rheumatoid arthritis and reversal by anti-TNF $\alpha$ therapy. J. Exp. Med. 2004, 200, 277-285. [CrossRef] [PubMed]

28. Ou, L.-S.; Goleva, E.; Hall, C.; Leung, D.Y. T regulatory cells in atopic dermatitis and subversion of their activity by superantigens. J. Allergy Clin. Immunol. 2004, 113, 756-763. [CrossRef] [PubMed]

29. Veldman, C.; Höhne, A.; Dieckmann, D.; Schuler, G.; Hertl, M. Type I regulatory T cells specific for desmoglein 3 are more frequently detected in healthy individuals than in patients with pemphigus vulgaris. J. Immunol. 2004, 172, 6468-6475. [CrossRef] [PubMed]

30. Sugiyama, H.; Gyulai, R.; Toichi, E.; Garaczi, E.; Shimada, S.; Stevens, S.R.; McCormick, T.S.; Cooper, K.D. Dysfunctional blood and target tissue $\mathrm{CD} 4{ }^{+} \mathrm{CD} 25$ high regulatory $\mathrm{T}$ cells in psoriasis: Mechanism underlying unrestrained pathogenic effector T cell proliferation. J. Immunol. 2005, 174, 164-173. [CrossRef] [PubMed]

31. Albanesi, C.; de Pità, O.; Girolomoni, G. Resident skin cells in psoriasis: A special look at the pathogenetic functions of keratinocytes. Clin. Dermatol. 2007, 25, 581-588. [CrossRef] [PubMed]

32. Morizane, S.; Yamasaki, K.; Mühleisen, B.; Kotol, P.F.; Murakami, M.; Aoyama, Y.; Iwatsuki, K.; Hata, T.; Gallo, R.L. Cathelicidin antimicrobial peptide LL-37 in psoriasis enables keratinocyte reactivity against TLR9 ligands. J. Investig. Dermatol. 2012, 132, 135-143. [CrossRef] [PubMed]

33. Bata-Csörgö, Z.; Szell, M. The psoriatic keratinocytes. Expert Rev. Dermatol. 2012, 7, 473-481. [CrossRef]

34. Piruzian, E.; Bruskin, S.; Ishkin, A.; Abdeev, R.; Moshkovskii, S.; Melnik, S.; Nikolsky, Y.; Nikolskaya, T. Integrated network analysis of transcriptomic and proteomic data in psoriasis. BMC Syst. Biol. 2010, 4, 41. [CrossRef] [PubMed]

35. Bowcock, A.M.; Krueger, J.G. Getting under the skin: The immunogenetics of psoriasis. Nat. Rev. Immunol. 2005, 5, 699-711. [CrossRef] [PubMed]

36. Mansbridge, J.N.; Knapp, A.M.; Strefling, A.M. Evidence for an alternative pathway of keratinocyte maturation in psoriasis from an antigen found in psoriatic but not normal epidermis. J. Investig. Dermatol. 1984, 83, 296-301. [CrossRef] [PubMed]

37. Gröne, A. Keratinocytes and cytokines. Vet. Immunol. Immunopathol. 2002, 88, 1-12. [CrossRef]

38. Groves, R.W.; Sherman, L.; Mizutani, H.; Dower, S.K.; Kupper, T.S. Detection of interleukin-1 receptors in human epidermis. Induction of the type II receptor after organ culture and in psoriasis. Am. J. Pathol. 1994, 145, 1048-1056. [PubMed]

39. Braff, M.H.; Bardan, A.; Nizet, V.; Gallo, R.L. Cutaneous defense mechanisms by antimicrobial peptides. J. Investig. Dermatol. 2005, 125, 9-13. [CrossRef] [PubMed]

40. Duell, E.A.; Ellis, C.N.; Voorhees, J.J. Determination of 5, 12, and 15-lipoxygenase products in keratomed biopsies of normal and psoriatic skin. J. Investig. Dermatol. 1988, 91, 446-450. [CrossRef] [PubMed]

41. Shirakata, Y.; Komurasaki, T.; Toyoda, H.; Hanakawa, Y.; Yamasaki, K.; Tokumaru, S.; Sayama, K.; Hashimoto, K. Epiregulin, a novel member of the epidermal growth factor family, is an autocrine growth factor in normal human keratinocytes. J. Biol. Chem. 2000, 275, 5748-5753. [CrossRef] [PubMed]

42. Pastore, S.; Mascia, F.; Mariani, V.; Girolomoni, G. The epidermal growth factor receptor system in skin repair and inflammation. J. Investig. Dermatol. 2008, 128, 1365-1374. [CrossRef] [PubMed] 
43. Detmar, M.; Brown, L.F.; Claffey, K.P.; Yeo, K.-T.; Kocher, O.; Jackman, R.W.; Berse, B.; Dvorak, H.F. Overexpression of vascular permeability factor/vascular endothelial growth factor and its receptors in psoriasis. J. Exp. Med. 1994, 180, 1141-1146. [CrossRef] [PubMed]

44. Finch, P.W.; Murphy, F.; Cardinale, I.; Krueger, J.G. Altered expression of keratinocyte growth factor and its receptor in psoriasis. Am. J. Pathol. 1997, 151, 1619-1628. [PubMed]

45. Nagy, N.; Bata-Csörgő, Z.; Kopasz, N.; Szeg, C.; Pivarcsi, A.; Koreck, A.; Dobozy, A.; Kemény, L.; Széll, M. The expression of keratinocyte growth factor receptor (FGFR2-IIIb) correlates with the high proliferative rate of HaCaT keratinocytes. Exp. Dermatol. 2006, 15, 596-605. [CrossRef] [PubMed]

46. Andreadis, S.T.; Hamoen, K.E.; Yarmush, M.L.; Morgan, J.R. Keratinocyte growth factor induces hyperproliferation and delays differentiation in a skin equivalent model system. FASEB J. 2001, 15, 898-906. [CrossRef] [PubMed]

47. Nickoloff, B.J.; Xin, H.; Nestle, F.O.; Qin, J.-Z. The cytokine and chemokine network in psoriasis. Clin. Dermatol. 2007, 25, 568-573. [CrossRef] [PubMed]

48. Egawa, G.; Kabashima, K. Skin as a peripheral lymphoid organ: Revisiting the concept of skin-associated lymphoid tissues. J. Investig. Dermatol. 2011, 131, 2178-2185. [CrossRef] [PubMed]

49. Kupper, T.S.; Fuhlbrigge, R.C. Immune surveillance in the skin: Mechanisms and clinical consequences. Nat. Rev. Immunol. 2004, 4, 211-222. [CrossRef] [PubMed]

50. Boyman, O.; Conrad, C.; Tonel, G.; Gilliet, M.; Nestle, F.O. The pathogenic role of tissue-resident immune cells in psoriasis. Trends Immunol. 2007, 28, 51-57. [CrossRef] [PubMed]

51. Clark, R.A.; Chong, B.; Mirchandani, N.; Brinster, N.K.; Yamanaka, K.-I.; Dowgiert, R.K.; Kupper, T.S. The vast majority of CLA+ T cells are resident in normal skin. J. Immunol. 2006, 176, 4431-4439. [CrossRef] [PubMed]

52. Nickoloff, B.J. Skin innate immune system in psoriasis: Friend or foe? J. Clin. Investig. 1999, 104, 1161-1164. [CrossRef] [PubMed]

53. Nestle, F.; Zheng, X.-G.; Thompson, C.; Turka, L.; Nickoloff, B. Characterization of dermal dendritic cells obtained from normal human skin reveals phenotypic and functionally distinctive subsets. J. Immunol. 1993, 151, 6535-6545. [PubMed]

54. Boyman, O.; Hefti, H.P.; Conrad, C.; Nickoloff, B.J.; Suter, M.; Nestle, F.O. Spontaneous development of psoriasis in a new animal model shows an essential role for resident T cells and tumor necrosis factor- $\alpha$. J. Exp. Med. 2004, 199, 731-736. [CrossRef] [PubMed]

55. Kanamori, H.; Tanaka, M.; Kawaguchi, H.; Yamaji, S.; Fujimaki, K.; Tomita, N.; Fujisawa, S.; Ishigatsubo, Y. Resolution of psoriasis following allogeneic bone marrow transplantation for chronic myelogenous leukemia: Case report and review of the literature. Am. J. Hematol. 2002, 71, 41-44. [CrossRef] [PubMed]

56. Barnes, P.J.; Karin, M. Nuclear factor- $\mathrm{kB}-\mathrm{A}$ pivotal transcription factor in chronic inflammatory diseases. N. Engl. J. Med. 1997, 336, 1066-1071. [CrossRef] [PubMed]

57. Schreck, R.; Albermann, K.; Baeuerle, P.A. Nuclear factor $\kappa B$ : An oxidative stress-responsive transcription factor of eukaryotic cells (a review). Free Radic. Res. Commun. 1992, 17, 221-237. [CrossRef] [PubMed]

58. Lizzul, P.F.; Aphale, A.; Malaviya, R.; Sun, Y.; Masud, S.; Dombrovskiy, V.; Gottlieb, A.B. Differential expression of phosphorylated NF- $\mathrm{k}$ / RelA in normal and psoriatic epidermis and downregulation of NF- $\mathrm{k}$ in response to treatment with etanercept. J. Investig. Dermatol. 2005, 124, 1275-1283. [CrossRef] [PubMed]

59. Moorchung, N.; Kulaar, J.S.; Chatterjee, M.; Vasudevan, B.; Tripathi, T.; Dutta, V. Role of NF- $\mathrm{kB}$ in the pathogenesis of psoriasis elucidated by its staining in skin biopsy specimens. Int. J. Dermatol. 2014, 53, 570-574. [CrossRef] [PubMed]

60. Zhu, H.; Lou, F.; Yin, Q.; Gao, Y.; Sun, Y.; Bai, J.; Xu, Z.; Liu, Z.; Cai, W.; Ke, F. RIG-I antiviral signaling drives interleukin-23 production and psoriasis-like skin disease. EMBO Mol. Med. 2017, 9, 589-604. [CrossRef] [PubMed]

61. Swindell, W.R.; Stuart, P.E.; Sarkar, M.K.; Voorhees, J.J.; Elder, J.T.; Johnston, A.; Gudjonsson, J.E. Cellular dissection of psoriasis for transcriptome analyses and the post-GWAS era. BMC Med. Genom. 2014, 7, 27. [CrossRef] [PubMed]

62. Debnath, B.; Xu, S.; Neamati, N. Small molecule inhibitors of signal transducer and activator of transcription 3 (Stat3) protein. J. Med. Chem. 2012, 55, 6645-6668. [CrossRef] [PubMed] 
63. Andrés, R.M.; Hald, A.; Johansen, C.; Kragballe, K.; Iversen, L. Studies of Jak/STAT3 expression and signalling in psoriasis identifies STAT3-Ser727 phosphorylation as a modulator of transcriptional activity. Exp. Dermatol. 2013, 22, 323-328. [CrossRef] [PubMed]

64. Sano, S.; Chan, K.S.; Carbajal, S.; Clifford, J.; Peavey, M.; Kiguchi, K.; Itami, S.; Nickoloff, B.J.; DiGiovanni, J. Stat3 links activated keratinocytes and immunocytes required for development of psoriasis in a novel transgenic mouse model. Nat. Med. 2005, 11, 43-49. [CrossRef] [PubMed]

65. Tsuji, K.; Inouye, H.; Nose, Y.; Sasazuki, T.; Ozawa, A.; Ohkido, M. Further study on HLA-A, B, C, D, DR and haplotype antigen frequencies in psoriasis vulgaris. Acta Derm. Venereol. Suppl. 1979, 87, 107-108.

66. Brenner, W.; Gschnait, F.; Mayr, W. HLA B13, B17, B37 and Cw6 in psoriasis vulgaris: Association with the age of onset. Arch. Dermatol. Res. 1978, 262, 337-339. [CrossRef] [PubMed]

67. Tiilikainen, A.; Lassus, A.; Karvonen, J.; Vartiainen, P.; Julin, M. Psoriasis and HLA-Cw6. Br. J. Dermatol. 1980, 102, 179-184. [CrossRef] [PubMed]

68. Russell, T.J.; Schultes, L.M.; Kuban, D.J. Histocompatibility (HL-A) antigens associated with psoriasis. N. Engl. J. Med. 1972, 287, 738-740. [CrossRef] [PubMed]

69. Roberson, E.D.; Bowcock, A.M. Psoriasis genetics: Breaking the barrier. Trends Genet. 2010, 26, 415-423. [CrossRef] [PubMed]

70. Gao, J.; Sun, L.; Zhang, X. The Genetic Progress of Psoriasis in the Han Chinese Population. J. Investig. Dermatol. Symp. Proc. 2015, 17, 46-47. [CrossRef] [PubMed]

71. Mahil, S.K.; Capon, F.; Barker, J.N. Genetics of psoriasis. Dermatol. Clin. 2015, 33, 1-11. [CrossRef] [PubMed]

72. Guðjónsson, J.E.; Valdimarsson, H.; Kárason, A.; Antonsdóttir, A.A.; Rúnarsdóttir, E.H.; Gulcher, J.R.; Stefánsson, K. HLA-Cw6-positive and HLA-Cw6-negative patients with psoriasis vulgaris have distinct clinical features. J. Investig. Dermatol. 2002, 118, 362-365. [CrossRef] [PubMed]

73. Balendran, N.; Clough, R.L.; Arguello, J.R.; Barber, R.; Veal, C.; Jones, A.B.; Rosbotham, J.L.; Little, A.-M.; Madrigal, A.; Barker, J.N. Characterization of the major susceptibility region for psoriasis at chromosome 6p21.3. J. Investig. Dermatol. 1999, 113, 322-328. [CrossRef] [PubMed]

74. Oka, A.; Tamiya, G.; Tomizawa, M.; Ota, M.; Katsuyama, Y.; Makino, S.; Shiina, T.; Yoshitome, M.; Iizuka, M.; Sasao, Y. Association analysis using refined microsatellite markers localizes a susceptibility locus for psoriasis vulgaris within a $111 \mathrm{~kb}$ segment telomeric to the HLA-C gene. Hum. Mol. Genet. 1999, 8, 2165-2170. [CrossRef] [PubMed]

75. Nair, R.P.; Stuart, P.; Henseler, T.; Jenisch, S.; Chia, N.V.; Westphal, E.; Schork, N.J.; Kim, J.; Lim, H.W.; Christophers, E. Localization of psoriasis-susceptibility locus PSORS1 to a 60-kb interval telomeric to HLA-C. Am. J. Hum. Genet. 2000, 66, 1833-1844. [CrossRef] [PubMed]

76. Jordan, C.T.; Cao, L.; Roberson, E.D.; Pierson, K.C.; Yang, C.-F.; Joyce, C.E.; Ryan, C.; Duan, S.; Helms, C.A.; Liu, Y. PSORS2 is due to mutations in CARD14. Am. J. Hum. Genet. 2012, 90, 784-795. [CrossRef] [PubMed]

77. Helms, C.; Cao, L.; Krueger, J.G.; Wijsman, E.M.; Chamian, F.; Gordon, D.; Heffernan, M.; Daw, J.A.W.; Robarge, J.; Ott, J. A putative RUNX1 binding site variant between SLC9A3R1 and NAT9 is associated with susceptibility to psoriasis. Nat. Genet. 2003, 35, 349-356. [CrossRef] [PubMed]

78. Capon, F.; Semprini, S.; Novelli, G.; Chimenti, S.; Fabrizi, G.; Zambruno, G.; Murgia, S.; Carcassi, C.; Fazio, M.; Mingarelli, R. Fine mapping of the PSORS4 psoriasis susceptibility region on chromosome 1q21. J. Investig. Dermatol. 2001, 116, 728-730. [CrossRef] [PubMed]

79. Ellinghaus, E.; Ellinghaus, D.; Stuart, P.E.; Nair, R.P.; Debrus, S.; Raelson, J.V.; Belouchi, M.; Fournier, H.; Reinhard, C.; Ding, J.; et al. Genome-wide association study identifies a psoriasis susceptibility locus at TRAF3IP2. Nat. Genet. 2010, 42, 991-995. [CrossRef] [PubMed]

80. Tsoi, L.C.; Spain, S.L.; Knight, J.; Ellinghaus, E.; Stuart, P.E.; Capon, F.; Ding, J.; Li, Y.; Tejasvi, T.; Gudjonsson, J.E. Identification of 15 new psoriasis susceptibility loci highlights the role of innate immunity. Nat. Genet. 2012, 44, 1341-1348. [CrossRef] [PubMed]

81. Bowcock, A.M. The genetics of psoriasis and autoimmunity. Annu. Rev. Genom. Hum. Genet. 2005, 6, 93-122. [CrossRef] [PubMed]

82. Feng, B.-J.; Sun, L.-D.; Soltani-Arabshahi, R.; Bowcock, A.M.; Nair, R.P.; Stuart, P.; Elder, J.T.; Schrodi, S.J.; Begovich, A.B.; Abecasis, G.R. Multiple Loci within the major histocompatibility complex confer risk of psoriasis. PLoS Genet. 2009, 5, e1000606. [CrossRef] [PubMed] 
83. Genetic Analysis of Psoriasis Consortium \& the Wellcome Trust Case Control Consortium 2; Strange, A.; Capon, F.; Spencer, C.C.; Knight, J.; Weale, M.E.; Allen, M.H.; Barton, A.; Band, G.A.; Bellenguez, C.; et al. genome-wide association study identifies new psoriasis susceptibility loci and an interaction between HLA-C and ERAP1. Nat. Genet. 2010, 42, 985-990.

84. Tamari, M.; Saeki, H.; Hayashi, M.; Umezawa, Y.; Ito, T.; Fukuchi, O.; Nobeyama, Y.; Yanaba, K.; Nakagawa, H.; Tsunemi, Y. An association study of 36 psoriasis susceptibility loci for psoriasis vulgaris and atopic dermatitis in a Japanese population. J. Dermatol. Sci. 2014, 76, 156-157. [CrossRef] [PubMed]

85. Picard, C.; Dogniaux, S.; Chemin, K.; Maciorowski, Z.; Lim, A.; Mazerolles, F.; Rieux-Laucat, F.; Stolzenberg, M.C.; Debre, M.; Magny, J.P. Hypomorphic mutation of ZAP70 in human results in a late onset immunodeficiency and no autoimmunity. Eur. J. Immunol. 2009, 39, 1966-1976. [CrossRef] [PubMed]

86. Madonna, S.; Scarponi, C.; Pallotta, S.; Cavani, A.; Albanesi, C. Anti-apoptotic effects of suppressor of cytokine signaling 3 and 1 in psoriasis. Cell Death Dis. 2012, 3, e334. [CrossRef] [PubMed]

87. Tsunemi, Y.; Saeki, H.; Nakamura, K.; Sekiya, T.; Hirai, K.; Fujita, H.; Asano, N.; Kishimoto, M.; Tanida, Y.; Kakinuma, T.; et al. Interleukin-12 p40 gene (IL12B) 3'-untranslated region polymorphism is associated with susceptibility to atopic dermatitis and psoriasis vulgaris. J. Dermatol. Sci. 2002, 30, 161-166. [CrossRef]

88. Nair, R.P.; Duffin, K.C.; Helms, C.; Ding, J.; Stuart, P.E.; Goldgar, D.; Gudjonsson, J.E.; Li, Y.; Tejasvi, T.; Feng, B.-J. Genome-wide scan reveals association of psoriasis with IL-23 and NF-кB pathways. Nat. Genet. 2009, 41, 199-204. [CrossRef] [PubMed]

89. Garber, K. Genetics: Deep exploration. Nature 2012, 492, S56-S57. [CrossRef] [PubMed]

90. Bijlmakers, M.-J.; Kanneganti, S.K.; Barker, J.N.; Trembath, R.C.; Capon, F. Functional analysis of the RNF114 psoriasis susceptibility gene implicates innate immune responses to double-stranded RNA in disease pathogenesis. Hum. Mol. Genet. 2011, 20, 3129-3137. [CrossRef] [PubMed]

91. Stuart, P.E.; Nair, R.P.; Ellinghaus, E.; Ding, J.; Tejasvi, T.; Gudjonsson, J.E.; Li, Y.; Weidinger, S.; Eberlein, B.; Gieger, C. Genome-wide association analysis identifies three psoriasis susceptibility loci. Nat. Genet. 2010, 42, 1000-1004. [CrossRef] [PubMed]

92. Galimova, E.; Akhmetova, V.; Latipov, B.; Kingo, K.; Rätsep, R.; Traks, T.; Kõks, S.; Khusnutdinova, E. Analysis of genetic variants of class II cytokine and their receptor genes in psoriasis patients of two ethnic groups from the Volga-Ural region of Russia. J. Dermatol. Sci. 2012, 68, 9-18. [CrossRef] [PubMed]

93. Munir, S.; ber Rahman, S.; Rehman, S.; Saba, N.; Ahmad, W.; Nilsson, S.; Mazhar, K.; Naluai, Å.T. Association analysis of GWAS and candidate gene loci in a Pakistani population with psoriasis. Mol. Immunol. 2015, 64, 190-194. [CrossRef] [PubMed]

94. Tsoi, L.C.; Stuart, P.E.; Tian, C.; Gudjonsson, J.E.; Das, S.; Zawistowski, M.; Ellinghaus, E.; Barker, J.N.; Chandran, V.; Dand, N. Large scale meta-analysis characterizes genetic architecture for common psoriasis associated variants. Nat. Commun. 2017, 8, 15382. [CrossRef] [PubMed]

95. Ellinghaus, E.; Stuart, P.E.; Ellinghaus, D.; Nair, R.P.; Debrus, S.; Raelson, J.V.; Belouchi, M.; Tejasvi, T.; Li, Y.; Tsoi, L.C. Genome-wide meta-analysis of psoriatic arthritis identifies susceptibility locus at REL. J. Investig. Dermatol. 2012, 132, 1133-1140. [CrossRef] [PubMed]

96. Mauro, C.; Pacifico, F.; Lavorgna, A.; Mellone, S.; Iannetti, A.; Acquaviva, R.; Formisano, S.; Vito, P.; Leonardi, A. ABIN-1 binds to NEMO/IKK $\gamma$ and co-operates with A20 in inhibiting NF-KB. J. Biol. Chem. 2006, 281, 18482-18488. [CrossRef] [PubMed]

97. Chandran, V. The genetics of psoriasis and psoriatic arthritis. Clin. Rev. Allergy Immunol. 2013, 44, 149-156. [CrossRef] [PubMed]

98. Zhang, X.-J.; Huang, W.; Yang, S.; Sun, L.-D.; Zhang, F.-Y.; Zhu, Q.-X.; Zhang, F.-R.; Zhang, C.; Du, W.-H.; $\mathrm{Pu}, \mathrm{X}$.-M. Psoriasis genome-wide association study identifies susceptibility variants within LCE gene cluster at 1q21. Nat. Genet. 2009, 41, 205-210. [CrossRef] [PubMed]

99. De Cid, R.; Riveira-Munoz, E.; Zeeuwen, P.L.; Robarge, J.; Liao, W.; Dannhauser, E.N.; Giardina, E.; Stuart, P.E.; Nair, R.; Helms, C. Deletion of the late cornified envelope LCE3B and LCE3C genes as a susceptibility factor for psoriasis. Nat. Genet. 2009, 41, 211-215. [CrossRef] [PubMed]

100. Indhumathi, S.; Rajappa, M.; Chandrashekar, L.; Ananthanarayanan, P.; Thappa, D.; Negi, V. Investigation of association of the IL-12B and IL-23R genetic variations with psoriatic risk in a South Indian Tamil cohort. Hum. Immunol. 2016, 77, 54-62. [CrossRef] [PubMed]

101. Sun, L.; Zhang, X. The immunological and genetic aspects in psoriasis. In Applied Informatics; Springer: Berlin, Germany, 2014; p. 3. 
102. Wu, L.-S.; Li, F.-F.; Liu, S.; Su, J.; Kuang, Y.-H.; Chen, C.; Xie, X.-Y.; Jiang, M.-H.; Chen, M.-L.; Chen, X. The association between GJB2 gene polymorphism and psoriasis: A verification study. Arch. Dermatol. Res. 2012, 304, 769-772.

103. Tang, H.; Jin, X.; Li, Y.; Jiang, H.; Tang, X.; Yang, X.; Cheng, H.; Qiu, Y.; Chen, G.; Mei, J. A large-scale screen for coding variants predisposing to psoriasis. Nat. Genet. 2014, 46, 45-50. [CrossRef] [PubMed]

104. Sheng, Y.; Jin, X.; Xu, J.; Gao, J.; Du, X.; Duan, D.; Li, B.; Zhao, J.; Zhan, W.; Tang, H. Sequencing-based approach identified three new susceptibility loci for psoriasis. Nat. Commun. 2014, 5, 4331. [CrossRef] [PubMed]

105. Lu, Q. The critical importance of epigenetics in autoimmunity. J. Autoimmun. 2013, 41, 1-5. [CrossRef] [PubMed]

106. Brandrup, F.; Hauge, M.; Henningsen, K.; Eriksen, B. Psoriasis in an unselected series of twins. Arch. Dermatol. 1978, 114, 874-878. [CrossRef] [PubMed]

107. Grjibovski, A.; Olsen, A.; Magnus, P.; Harris, J. Psoriasis in Norwegian twins: Contribution of genetic and environmental effects. J. Eur. Acad. Dermatol. Venereol. 2007, 21, 1337-1343. [CrossRef] [PubMed]

108. Zhang, P.; Su, Y.; Chen, H.; Zhao, M.; Lu, Q. Abnormal DNA methylation in skin lesions and PBMCs of patients with psoriasis vulgaris. J. Dermatol. Sci. 2010, 60, 40-42. [CrossRef] [PubMed]

109. Roman-Gomez, J.; Jimenez-Velasco, A.; Agirre, X.; Castillejo, J.; Navarro, G.; Barrios, M.; Andreu, E.J.; Prosper, F.; Heiniger, A.; Torres, A. Transcriptional silencing of the Dickkopfs-3 (Dkk-3) gene by CpG hypermethylation in acute lymphoblastic leukaemia. Br. J. Cancer 2004, 91, 707-713. [CrossRef] [PubMed]

110. Zhang, K.; Zhang, R.; Li, X.; Yin, G.; Niu, X. Promoter methylation status of p15 and p21 genes in HPP-CFCs of bone marrow of patients with psoriasis. Eur. J. Dermatol. 2009, 19, 141-146. [PubMed]

111. Wrone-Smith, T.; Mitra, R.S.; Thompson, C.B.; Jasty, R.; Castle, V.P.; Nickoloff, B.J. Keratinocytes derived from psoriatic plaques are resistant to apoptosis compared with normal skin. Am. J. Pathol. 1997, 151, 1321-1329. [PubMed]

112. Chen, M.; Chen, Z.Q.; Cui, P.G.; Yao, X.; Li, Y.M.; Li, A.S.; Gong, J.Q.; Cao, Y.H. The methylation pattern of p16INK4a gene promoter in psoriatic epidermis and its clinical significance. Br. J. Dermatol. 2008, 158, 987-993. [CrossRef] [PubMed]

113. Zong, W.; Ge, Y.; Han, Y.; Yang, X.; Li, Q.; Chen, M. Hypomethylation of HLA-DRB1 and its clinical significance in psoriasis. Oncotarget 2017, 8, 12323-12332. [CrossRef] [PubMed]

114. Zhang, P.; Su, Y.; Lu, Q. Epigenetics and psoriasis. J. Eur. Acad. Dermatol. Venereol. 2012, 26, $399-403$. [CrossRef] [PubMed]

115. Zhang, P.; Su, Y.; Zhao, M.; Huang, W.; Lu, Q. Abnormal histone modifications in PBMCs from patients with psoriasis vulgaris. Eur. J. Dermatol. 2011, 21, 552-557. [PubMed]

116. Tovar-Castillo, L.E.; Cancino-Díaz, J.C.; García-Vázquez, F.; Cancino-Gómez, F.G.; León-Dorantes, G.; Blancas-González, F.; Jiménez-Zamudio, L.; García-Latorre, E.; Cancino-Díaz, M.E. Under-expression of VHL and over-expression of HDAC-1, HIF-1 $\alpha$, LL-37, and IAP-2 in affected skin biopsies of patients with psoriasis. Int. J. Dermatol. 2007, 46, 239-246. [CrossRef] [PubMed]

117. McLaughlin, F.; Thangue, N.B.L. Histone deacetylase inhibitors in psoriasis therapy. Curr. Drug Targets Inflamm. Allergy 2004, 3, 213-219. [CrossRef] [PubMed]

118. Shuttleworth, S.J.; Bailey, S.G.; Townsend, P.A. Histone deacetylase inhibitors: New promise in the treatment of immune and inflammatory diseases. Curr. Drug Targets 2010, 11, 1430-1438. [CrossRef] [PubMed]

119. Rebane, A.; Runnel, T.; Aab, A.; Maslovskaja, J.; Rückert, B.; Zimmermann, M.; Plaas, M.; Kärner, J.; Treis, A.; Pihlap, M. MicroRNA-146a alleviates chronic skin inflammation in atopic dermatitis through suppression of innate immune responses in keratinocytes. J. Allergy Clin. Immunol. 2014, 134, 836-847. [CrossRef] [PubMed]

120. Hermann, H.; Runnel, T.; Aab, A.; Baurecht, H.; Rodriguez, E.; Magilnick, N.; Urgard, E.; Šahmatova, L.; Prans, E.; Maslovskaja, J. miR-146b probably assists miRNA-146a in the suppression of keratinocyte proliferation and inflammatory responses in psoriasis. J. Investig. Dermatol. 2017, 137, 1945-1954. [CrossRef] [PubMed]

121. Xu, N.; Brodin, P.; Wei, T.; Meisgen, F.; Eidsmo, L.; Nagy, N.; Kemeny, L.; Ståhle, M.; Sonkoly, E.; Pivarcsi, A. MiR-125b, a microRNA downregulated in psoriasis, modulates keratinocyte proliferation by targeting FGFR2. J. Investig. Dermatol. 2011, 131, 1521-1529. [CrossRef] [PubMed] 
122. Tili, E.; Michaille, J.-J.; Cimino, A.; Costinean, S.; Dumitru, C.D.; Adair, B.; Fabbri, M.; Alder, H.; Liu, C.G.; Calin, G.A. Modulation of miR-155 and miR-125b levels following lipopolysaccharide/TNF- $\alpha$ stimulation and their possible roles in regulating the response to endotoxin shock. J. Immunol. 2007, 179, 5082-5089. [CrossRef] [PubMed]

123. Taganov, K.D.; Boldin, M.P.; Chang, K.-J.; Baltimore, D. NF-kB-dependent induction of microRNA miR-146, an inhibitor targeted to signaling proteins of innate immune responses. Proc. Natl. Acad. Sci. USA 2006, 103, 12481-12486. [CrossRef] [PubMed]

124. Srivastava, A.; Nikamo, P.; Lohcharoenkal, W.; Li, D.; Meisgen, F.; Landén, N.X.; Ståhle, M.; Pivarcsi, A.; Sonkoly, E. MicroRNA-146a suppresses IL-17-mediated skin inflammation and is genetically associated with psoriasis. J. Allergy Clin. Immunol. 2017, 139, 550-561. [CrossRef] [PubMed]

125. Wang, M.-J.; Xu, Y.-Y.; Huang, R.-Y.; Chen, X.-M.; Chen, H.-M.; Han, L.; Yan, Y.-H.; Lu, C.-J. Role of an imbalanced miRNAs axis in pathogenesis of psoriasis: Novel perspectives based on review of the literature. Oncotarget 2017, 8, 5498-5507. [CrossRef] [PubMed]

126. Meisgen, F.; Xu, N.; Wei, T.; Janson, P.C.; Obad, S.; Broom, O.; Nagy, N.; Kauppinen, S.; Kemény, L.; Ståhle, M. MiR-21 is up-regulated in psoriasis and suppresses T cell apoptosis. Exp. Dermatol. 2012, 21, 312-314. [CrossRef] [PubMed]

127. Guinea-Viniegra, J.; Jiménez, M.; Schonthaler, H.B.; Navarro, R.; Delgado, Y.; Concha-Garzón, M.J.; Tschachler, E.; Obad, S.; Daudén, E.; Wagner, E.F. Targeting miR-21 to treat psoriasis. Sci. Transl. Med. 2014, 6, 225. [CrossRef] [PubMed]

128. Xu, N.; Meisgen, F.; Butler, L.M.; Han, G.; Wang, X.-J.; Söderberg-Nauclér, C.; Ståhle, M.; Pivarcsi, A.; Sonkoly, E. MicroRNA-31 is overexpressed in psoriasis and modulates inflammatory cytokine and chemokine production in keratinocytes via targeting serine/threonine kinase 40. J. Immunol. 2013, 190, 678-688. [CrossRef] [PubMed]

129. Yan, S.; Xu, Z.; Lou, F.; Zhang, L.; Ke, F.; Bai, J.; Liu, Z.; Liu, J.; Wang, H.; Zhu, H. NF-kB-induced microRNA-31 promotes epidermal hyperplasia by repressing protein phosphatase 6 in psoriasis. Nat. Commun. 2015, 6, 7652. [CrossRef] [PubMed]

130. Peng, H.; Kaplan, N.; Hamanaka, R.B.; Katsnelson, J.; Blatt, H.; Yang, W.; Hao, L.; Bryar, P.J.; Johnson, R.S.; Getsios, S. microRNA-31/factor-inhibiting hypoxia-inducible factor 1 nexus regulates keratinocyte differentiation. Proc. Natl. Acad. Sci. USA 2012, 109, 14030-14034. [CrossRef] [PubMed]

131. Zhang, D.; Wang, J.; Wang, Z.; Zhang, T.; Shi, P.; Wang, X.; Zhao, F.; Liu, X.; Lin, X.; Pang, X. miR-136 modulates TGF- $\beta 1$-induced proliferation arrest by targeting PPP2R2A in keratinocytes. Biomed. Res. Int. 2015, 2015, 453518. [CrossRef] [PubMed]

132. Løvendorf, M.B.; Zibert, J.R.; Gyldenløve, M.; Røpke, M.A.; Skov, L. MicroRNA-223 and miR-143 are important systemic biomarkers for disease activity in psoriasis. J. Dermatol. Sci. 2014, 75, 133-139. [CrossRef] [PubMed]

133. Zhang, W.; Yi, X.; Guo, S.; Shi, Q.; Wei, C.; Li, X.; Gao, L.; Wang, G.; Gao, T.; Wang, L. A single-nucleotide polymorphism of miR-146a and psoriasis: An association and functional study. J. Cell. Mol. Med. 2014, 18, 2225-2234. [CrossRef] [PubMed]

134. Løvendorf, M.B.; Mitsui, H.; Zibert, J.R.; Røpke, M.A.; Hafner, M.; Dyring-Andersen, B.; Bonefeld, C.M.; Krueger, J.G.; Skov, L. Laser capture microdissection followed by next-generation sequencing identifies disease-related microRNAs in psoriatic skin that reflect systemic microRNA changes in psoriasis. Exp. Dermatol. 2015, 24, 187-193. [CrossRef] [PubMed]

135. Ichihara, A.; Jinnin, M.; Yamane, K.; Fujisawa, A.; Sakai, K.; Masuguchi, S.; Fukushima, S.; Maruo, K.; Ihn, H. microRNA-mediated keratinocyte hyperproliferation in psoriasis vulgaris. Br. J. Dermatol. 2011, 165, 1003-1010. [CrossRef] [PubMed]

136. Michel, C.I.; Malumbres, M. microRNA-203, Tumor suppression and beyond. Microrna 2013, 2, 118-126. [CrossRef] [PubMed]

137. Sonkoly, E.; Wei, T.; Janson, P.C.; Sääf, A.; Lundeberg, L.; Tengvall-Linder, M.; Norstedt, G.; Alenius, H.; Homey, B.; Scheynius, A. MicroRNAs: Novel regulators involved in the pathogenesis of psoriasis? PLoS ONE 2007, 2, e610. [CrossRef] [PubMed]

138. Zibert, J.R.; Løvendorf, M.B.; Litman, T.; Olsen, J.; Kaczkowski, B.; Skov, L. MicroRNAs and potential target interactions in psoriasis. J. Dermatol. Sci. 2010, 58, 177-185. [CrossRef] [PubMed] 
139. Lerman, G.; Avivi, C.; Mardoukh, C.; Barzilai, A.; Tessone, A.; Gradus, B.; Pavlotsky, F.; Barshack, I.; Polak-Charcon, S.; Orenstein, A. MiRNA expression in psoriatic skin: Reciprocal regulation of hsa-miR-99a and IGF-1R. PLoS ONE 2011, 6, e20916. [CrossRef] [PubMed]

140. Fu, D.; Yu, W.; Li, M.; Wang, H.; Liu, D.; Song, X.; Li, Z.; Tian, Z. MicroRNA-138 regulates the balance of Th1/Th2 via targeting RUNX3 in psoriasis. Immunol. Lett. 2015, 166, 55-62. [CrossRef] [PubMed]

141. Cao, J. The functional role of long non-coding RNAs and epigenetics. Biol. Proced. Online 2014, $16,11$. [CrossRef] [PubMed]

142. Haywood, M.; Rose, S.; Horswell, S.; Lees, M.; Fu, G.; Walport, M.; Morley, B.J. Overlapping BXSB congenic intervals, in combination with microarray gene expression, reveal novel lupus candidate genes. Genes Immun. 2006, 7, 250-263. [CrossRef] [PubMed]

143. Song, J.; Kim, D.; Han, J.; Kim, Y.; Lee, M.; Jin, E.-J. PBMC and exosome-derived Hotair is a critical regulator and potent marker for rheumatoid arthritis. Clin. Exp. Med. 2015, 15, 121-126. [CrossRef] [PubMed]

144. Sonkoly, E.; Bata-Csorgo, Z.; Pivarcsi, A.; Polyanka, H.; Kenderessy-Szabo, A.; Molnar, G.; Szentpali, K.; Bari, L.; Megyeri, K.; Mandi, Y. Identification and characterization of a novel, psoriasis susceptibility-related noncoding RNA gene, PRINS. J. Biol. Chem. 2005, 280, 24159-24167. [CrossRef] [PubMed]

145. Holm, S.; Sanchez, F.; Carlen, L.; Mallbris, L.; Ståhle, M.; O’brien, K. HLA-Cw 0602 Associates More Strongly to Psoriasis in the Swedish Population than Variants of the Novel 6p21.3 Gene PSORS1C3. Acta Derm. Venereol. 2005, 85, 2-8. [PubMed]

146. Chang, Y.-T.; Chou, C.; Shiao, Y.; Lin, M.; Yu, C.; Chen, C.; Huang, C.; Lee, D.; Liu, H.; Wang, W. Psoriasis vulgaris in Chinese individuals is associated with PSORS1C3 and CDSN genes. Br. J. Dermatol. 2006, 155, 663-669. [CrossRef] [PubMed]

147. Wolk, K.; Mallbris, L.; Larsson, P.; Rosenblad, A.; Vingård, E.; Ståhle, M. Excessive body weight and smoking associates with a high risk of onset of plaque psoriasis. Acta Derm. Venereol. 2009, 89, 492-497. [CrossRef] [PubMed]

148. Carrascosa, J.; Rocamora, V.; Fernandez-Torres, R.; Jimenez-Puya, R.; Moreno, J.; Coll-Puigserver, N.; Fonseca, E. Obesity and psoriasis: Inflammatory nature of obesity, relationship between psoriasis and obesity, and therapeutic implications. Actas Dermosifiliogr. 2014, 105, 31-44. [CrossRef] [PubMed]

149. Neimann, A.L.; Shin, D.B.; Wang, X.; Margolis, D.J.; Troxel, A.B.; Gelfand, J.M. Prevalence of cardiovascular risk factors in patients with psoriasis. J. Am. Acad. Dermatol. 2006, 55, 829-835. [CrossRef] [PubMed]

150. Qureshi, A.A.; Dominguez, P.L.; Choi, H.K.; Han, J.; Curhan, G. Alcohol intake and risk of incident psoriasis in US women: A prospective study. Arch. Dermatol. 2010, 146, 1364-1369. [CrossRef] [PubMed]

151. Adamzik, K.; McAleer, M.; Kirby, B. Alcohol and psoriasis: Sobering thoughts. Clin. Exp. Dermatol. 2013, 38, 819-822. [CrossRef] [PubMed]

152. Farkas, A.; Kemeny, L. Psoriasis and alcohol: Is cutaneous ethanol one of the missing links? Br. J. Dermatol. 2010, 162, 711-716. [CrossRef] [PubMed]

153. Farkas, Á.; Kemény, L.; Széll, M.; Dobozy, A.; Bata-Csörgő, Z. Ethanol and acetone stimulate the proliferation of HaCaT keratinocytes. Arch. Dermatol. Res. 2003, 295, 56-62. [CrossRef] [PubMed]

154. Park, B.S.; Youn, J.I. Factors influencing psoriasis: An analysis based upon the extent of involvement and clinical type. J. Dermatol. 1998, 25, 97-102. [CrossRef] [PubMed]

155. Heller, M.M.; Lee, E.S.; Koo, J. Stress as an influencing factor in psoriasis. Skin Ther. Lett. 2011, 16, 1-4.

156. Buske-Kirschbaum, A.; Ebrecht, M.; Kern, S.; Hellhammer, D. Endocrine stress responses in TH1-mediated chronic inflammatory skin disease (psoriasis vulgaris) - Do they parallel stress-induced endocrine changes in TH2-mediated inflammatory dermatoses (atopic dermatitis)? Psychoneuroendocrinology 2006, 31, 439-446. [CrossRef] [PubMed]

157. Evers, A.; Verhoeven, E.; Kraaimaat, F.; de Jong, E.; de Brouwer, S.; Schalkwijk, J.; Sweep, F.; van de Kerkhof, P. How stress gets under the skin: Cortisol and stress reactivity in psoriasis. Br. J. Dermatol. 2010, 163, 986-991. [CrossRef] [PubMed]

158. Breitling, L.P.; Yang, R.; Korn, B.; Burwinkel, B.; Brenner, H. Tobacco-smoking-related differential DNA methylation: 27K discovery and replication. Am. J. Hum. Genet. 2011, 88, 450-457. [CrossRef] [PubMed]

159. Kim, D.-H.; Nelson, H.H.; Wiencke, J.K.; Zheng, S.; Christiani, D.C.; Wain, J.C.; Mark, E.J.; Kelsey, K.T. p16INK4a and histology-specific methylation of CpG islands by exposure to tobacco smoke in non-small cell lung cancer. Cancer Res. 2001, 61, 3419-3424. [PubMed] 
160. Torii, K.; Saito, C.; Furuhashi, T.; Nishioka, A.; Shintani, Y.; Kawashima, K.; Kato, H.; Morita, A. Tobacco smoke is related to Th17 generation with clinical implications for psoriasis patients. Exp. Dermatol. 2011, 20, 371-373. [CrossRef] [PubMed]

161. Zeng, J.; Luo, S.; Huang, Y.; Lu, Q. Critical role of environmental factors in the pathogenesis of psoriasis. J. Dermatol. 2017, 44, 863-872. [CrossRef] [PubMed]

162. Woo, Y.R.; Jung, K.E.; Koo, D.W.; Lee, J.S. Vitamin D as a marker for disease severity in chronic urticaria and its possible role in pathogenesis. Ann. Dermatol. 2015, 27, 423-430. [CrossRef] [PubMed]

163. Kim, J.E.; Kim, J.S.; Cho, D.H.; Park, H.J. Molecular mechanisms of cutaneous inflammatory disorder: Atopic dermatitis. Int. J. Mol. Sci. 2016, 17, 1234. [CrossRef] [PubMed]

164. Woo, Y.R.; Lim, J.H.; Cho, D.H.; Park, H.J. Rosacea: Molecular mechanisms and management of a chronic cutaneous inflammatory condition. Int. J. Mol. Sci. 2016, 17, 1562. [CrossRef] [PubMed]

165. Hambly, R.; Kirby, B. The relevance of serum vitamin D in psoriasis: A review. Arch. Dermatol. Res. 2017, 499-517. [CrossRef] [PubMed]

166. Barrea, L.; Savanelli, M.C.; di Somma, C.; Napolitano, M.; Megna, M.; Colao, A.; Savastano, S. Vitamin D and its role in psoriasis: An overview of the dermatologist and nutritionist. Rev. Endocr. Metab. Disord. 2017, 18, 195-205. [CrossRef] [PubMed]

167. Kerkhof, P. Biological activity of vitamin D analogues in the skin, with special reference to antipsoriatic mechanisms. Br. J. Dermatol. 1995, 132, 675-682. [CrossRef] [PubMed]

168. Paller, A.S.; Siegfried, E.C.; Langley, R.G.; Gottlieb, A.B.; Pariser, D.; Landells, I.; Hebert, A.A.; Eichenfield, L.F.; Patel, V.; Creamer, K. Etanercept treatment for children and adolescents with plaque psoriasis. N. Engl. J. Med. 2008, 358, 241-251. [CrossRef] [PubMed]

169. Urdaneta, M.; Jethwa, H.; Sultan, R.; Abraham, S. A review on golimumab in the treatment of psoriatic arthritis. Immunotherapy 2017. [CrossRef] [PubMed]

170. Reich, K.; Ortonne, J.P.; Gottlieb, A.; Terpstra, I.; Coteur, G.; Tasset, C.; Mease, P. Successful treatment of moderate to severe plaque psoriasis with the PEGylated Fab' certolizumab pegol: Results of a phase II randomized, placebo-controlled trial with a re-treatment extension. Br. J. Dermatol. 2012, 167, 180-190. [CrossRef] [PubMed]

171. Lebwohl, M.; Strober, B.; Menter, A.; Gordon, K.; Weglowska, J.; Puig, L.; Papp, K.; Spelman, L.; Toth, D.; Kerdel, F. Phase 3 studies comparing brodalumab with ustekinumab in psoriasis. N. Engl. J. Med. 2015, 373, 1318-1328. [CrossRef] [PubMed]

172. Papp, K.; Griffiths, C.; Gordon, K.; Lebwohl, M.; Szapary, P.; Wasfi, Y.; Chan, D.; Hsu, M.C.; Ho, V.; Ghislain, P.-D. Long-term safety of ustekinumab in patients with moderate-to-severe psoriasis: Final results from 5 years of follow-up. Br. J. Dermatol. 2013, 168, 844-854. [CrossRef] [PubMed]

173. Papp, K.; Thaçi, D.; Reich, K.; Riedl, E.; Langley, R.; Krueger, J.; Gottlieb, A.; Nakagawa, H.; Bowman, E.; Mehta, A. Tildrakizumab (MK-3222), an anti-interleukin-23p19 monoclonal antibody, improves psoriasis in a phase IIb randomized placebo-controlled trial. Br. J. Dermatol. 2015, 173, 930-939. [CrossRef] [PubMed]

174. Reich, K.; Armstrong, A.W.; Foley, P.; Song, M.; Wasfi, Y.; Randazzo, B.; Li, S.; Shen, Y.-K.; Gordon, K.B. Efficacy and safety of guselkumab, an anti-interleukin-23 monoclonal antibody, compared with adalimumab for the treatment of patients with moderate to severe psoriasis with randomized withdrawal and retreatment: Results from the phase III, double-blind, placebo-and active comparator-controlled VOYAGE 2 trial. J. Am. Acad. Dermatol. 2017, 76, 418-431. [PubMed]

175. Papp, K.A.; Blauvelt, A.; Bukhalo, M.; Gooderham, M.; Krueger, J.G.; Lacour, J.-P.; Menter, A.; Philipp, S.; Sofen, H.; Tyring, S. Risankizumab versus Ustekinumab for Moderate-to-Severe Plaque Psoriasis. N. Engl. J. Med. 2017, 376, 1551-1560. [CrossRef] [PubMed]

176. Gordon, K.B.; Blauvelt, A.; Papp, K.A.; Langley, R.G.; Luger, T.; Ohtsuki, M.; Reich, K.; Amato, D.; Ball, S.G.; Braun, D.K. Phase 3 trials of ixekizumab in moderate-to-severe plaque psoriasis. N. Engl. J. Med. 2016, 375, 2101-2102. [CrossRef] [PubMed]

177. Mease, P.; McInnes, I.; Reich, K.; Nash, P.; Andersson, M.; Abrams, K.; Pricorp, L.; Fox, T. FRI0511 Secukinumab demonstrates consistent safety over long-term exposure in patients with psoriatic arthritis and moderate-to-severe plaque psoriasis: Updated pooled safety analyses. Ann. Rheum. Dis. 2017, 76, 683.

178. Punwani, N.; Scherle, P.; Flores, R.; Shi, J.; Liang, J.; Yeleswaram, S.; Levy, R.; Williams, W.; Gottlieb, A. Preliminary clinical activity of a topical JAK1/2 inhibitor in the treatment of psoriasis. J. Am. Acad. Dermatol. 2012, 67, 658-664. [CrossRef] [PubMed] 
179. Papp, K.; Menter, M.; Raman, M.; Disch, D.; Schlichting, D.; Gaich, C.; Macias, W.; Zhang, X.; Janes, J. A randomized phase $2 \mathrm{~b}$ trial of baricitinib, an oral Janus kinase (JAK) $1 /$ JAK2 inhibitor, in patients with moderate-to-severe psoriasis. Br. J. Dermatol. 2016, 174, 1266-1276. [CrossRef] [PubMed]

180. David, M.; Akerman, L.; Ziv, M.; Kadurina, M.; Gospodinov, D.; Pavlotsky, F.; Yankova, R.; Kouzeva, V.; Ramon, M.; Silverman, M. Treatment of plaque-type psoriasis with oral CF101, data from an exploratory randomized phase 2 clinical trial. J. Eur. Acad. Dermatol. Venereol. 2012, 26, 361-367. [CrossRef] [PubMed]

181. Wang, H.; Syrovets, T.; Kess, D.; Büchele, B.; Hainzl, H.; Lunov, O.; Weiss, J.M.; Scharffetter-Kochanek, K.; Simmet, T. Targeting NF- $\mathrm{BB}$ with a natural triterpenoid alleviates skin inflammation in a mouse model of psoriasis. J. Immunol. 2009, 183, 4755-4763. [CrossRef] [PubMed]

182. Papp, K.A.; Krueger, J.G.; Feldman, S.R.; Langley, R.G.; Thaci, D.; Torii, H.; Tyring, S.; Wolk, R.; Gardner, A.; Mebus, C. Tofacitinib, an oral Janus kinase inhibitor, for the treatment of chronic plaque psoriasis: Long-term efficacy and safety results from 2 randomized phase-III studies and 1 open-label long-term extension study. J. Am. Acad. Dermatol. 2016, 74, 841-850. [CrossRef] [PubMed]

183. Taylor, P.C. Anti-Tumor necrosis factor therapies. Curr. Opin. Rheumatol. 2001, 13, 164-169. [CrossRef] [PubMed]

184. Schopf, R.E.; Aust, H.; Knop, J. Treatment of psoriasis with the chimeric monoclonal antibody against tumor necrosis factor $\alpha$, infliximab. J. Am. Acad. Dermatol. 2002, 46, 886-891. [CrossRef] [PubMed]

185. Reich, K.; Nestle, F.O.; Papp, K.; Ortonne, J.-P.; Evans, R.; Guzzo, C.; Li, S.; Dooley, L.T.; Griffiths, C.E.; Investigators, E.S. Infliximab induction and maintenance therapy for moderate-to-severe psoriasis: A phase III, multicentre, double-blind trial. Lancet 2005, 366, 1367-1374. [CrossRef]

186. Weger, W. Current status and new developments in the treatment of psoriasis and psoriatic arthritis with biological agents. Br. J. Pharmacol. 2010, 160, 810-820. [CrossRef] [PubMed]

187. Puig, L.; Lopez, A.; Vilarrasa, E.; Garcia, I. Efficacy of biologics in the treatment of moderate-to-severe plaque psoriasis: A systematic review and meta-analysis of randomized controlled trials with different time points. J. Eur. Acad. Dermatol. Venereol. 2014, 28, 1633-1653. [CrossRef] [PubMed]

188. Oppmann, B.; Lesley, R.; Blom, B.; Timans, J.C.; Xu, Y.; Hunte, B.; Vega, F.; Yu, N.; Wang, J.; Singh, K. Novel p19 protein engages IL-12p40 to form a cytokine, IL-23, with biological activities similar as well as distinct from IL-12. Immunity 2000, 13, 715-725. [CrossRef]

189. Miossec, P.; Kolls, J.K. Targeting IL-17 and TH17 cells in chronic inflammation. Nat. Rev. Drug Discov. 2012, 11, 763-776. [CrossRef] [PubMed]

190. Fridman, J.S.; Scherle, P.A.; Collins, R.; Burn, T.; Neilan, C.L.; Hertel, D.; Contel, N.; Haley, P.; Thomas, B.; Shi, J. Preclinical evaluation of local JAK1 and JAK2 inhibition in cutaneous inflammation. J. Investig. Dermatol. 2011, 131, 1838-1844. [CrossRef] [PubMed]

191. Fishman, P.; Cohen, S. The A3 adenosine receptor (A3AR): Therapeutic target and predictive biological marker in rheumatoid arthritis. Clin. Rheumatol. 2016, 35, 2359-2362. [CrossRef] [PubMed]

192. Fishman, P.; Bar-Yehuda, S.; Liang, B.T.; Jacobson, K.A. Pharmacological and therapeutic effects of A3 adenosine receptor agonists. Drug Discov. Today 2012, 17, 359-366. [CrossRef] [PubMed]

(c) 2017 by the authors. Licensee MDPI, Basel, Switzerland. This article is an open access article distributed under the terms and conditions of the Creative Commons Attribution (CC BY) license (http:/ / creativecommons.org/licenses/by/4.0/). 